\title{
To the fauna of dung flies (Diptera: Scathophagidae) of Russian Far East
}

\section{К фауне двукрылых семейства Scathophagidae (Diptera) Аальнего Востока России}

\author{
A.L. Ozerov ${ }^{1}$, M.G. Krivosheina ${ }^{2}$

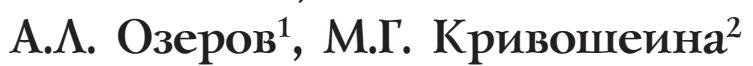

\author{
${ }^{1}$ Zoological Museum, Moscow Lomonosov State University, Bol'shaya Nikitskaya 6, Moscow 125009, Russia. \\ E-mail: ozerov2455@rambler.ru \\ 1 Зоологический музей, Московский государственный университет им. М.В. Ломоносова, Большая Никитская ул., 6, Москва \\ 125009, Россия. \\ ${ }^{2}$ A.N. Severtsov Institute of Ecology and Evolution, Russian Academy of Sciences, Moscow 119071, Russia. \\ E-mail: dipteramarina@rambler.ru \\ ${ }^{2}$ Институт проблем экологии и эволюции им. А.Н.Северцова РАН, Ленинский проспект 33, Москва 119071, Россия.
}

KEY WORDS: Diptera, Scathophagidae, new species, new synonym, Russian Far East.

КЛЮЧЕВЫЕ СЛОВА: Diptera, Scathophagidae, новый вид, новый синоним, Дальний Восток России.

ABSTRACT. A list of dung flies of Russian Far East is provided. A total of 98 species are mentioned for Russian Far East, 30 of which were not previously recorded: Allomyella crinipes (Ringdahl, 1928), Cleigastra apicalis (Meigen, 1826), Cordilura aemula (Collin, 1958), C. atrata (Zetterstedt, 1846), C. pudica (Meigen, 1826), C. sagittifera Gorodkov, 1974, C. ustulata (Zetterstedt, 1838), C. zaitzevi Gorodkov, 1974, Gimnomera cuneiventris (Zetterstedt, 1846), G. hirta (Hendel, 1930), G. lasiostoma (Becker, 1894), Hexamitocera loxocerata (Fallén, 1826), Megaphthalmoides unilineatus (Zetterstedt, 1838), Microprosopa heteromyzina (Zetterstedt, 1838), M. pallidicauda (Zetterstedt, 1838), Nanna flavipes (Fallén, 1819), N. leucostoma (Zetterstedt, 1846), Neochirosia veratri (Hendel, 1925), Orthacheta pilosa (Zetterstedt, 1838), Parallelomma sellatum (Hackman, 1956), P. vittatum (Meigen, 1826), Pogonota barbata (Zetterstedt, 1838), Scathophaga litorea (Fallén, 1819), S. mollis (Becker, 1894), S. tinctinervis (Becker, 1894), Spaziphora hydromyzina (Fallén, 1819), Trichopalpus fraternus (Meigen, 1826), T. (Huckettia) nearcticus (Vockeroth, 1987), T. nigribasis (Curran, 1927), T. obscurellus (Zetterstedt, 1846). Besides, genus Acanthocnema Becker, 1894 and Gimnomera lasiostoma are mentioned firstly for Russia and Scathophaga litorea (Fallén, 1819) is firstly discovered for Pacific coast.

3 species new to science are described: Acanthocnema vikhrevi sp.n. from Magadan Oblast, Cordilura kosterini sp.n. from Primorskiy Kray, and Cordilura monochroma sp.n. from Primorskiy Kray and Sakhalin Oblast. One new synonym is established: Scathophaga sychevskayae Ozerov, 2010 is a new synonym of Scathophaga mollis (Becker, 1894).

РЕЗЮМЕ. Приведен список двукрылых семейства Scathophagidae Дальнего Востока России, содержа- щий 98 видов, из которых 30 впервые отмечены для этой территории: Allomyella crinipes (Ringdahl, 1928), Cleigastra apicalis (Meigen, 1826), Cordilura aemula (Collin, 1958), C. atrata (Zetterstedt, 1846), C. pudica (Meigen, 1826), C. sagittifera Gorodkov, 1974, C. ustulata (Zetterstedt, 1838), C. zaitzevi Gorodkov, 1974, Gimnomera cuneiventris (Zetterstedt, 1846), G. hirta (Hendel, 1930), G. lasiostoma (Becker, 1894), Hexamitocera loxocerata (Fallén, 1826), Megaphthalmoides unilineatus (Zetterstedt, 1838), Microprosopa heteromyzina (Zetterstedt, 1838), M. pallidicauda (Zetterstedt, 1838), Nanna flavipes (Fallén, 1819), N. leucostoma (Zetterstedt, 1846), Neochirosia veratri (Hendel, 1925), Orthacheta pilosa (Zetterstedt, 1838), Parallelomma sellatum (Hackman, 1956), P. vittatum (Meigen, 1826), Pogonota barbata (Zetterstedt, 1838), Scathophaga litorea (Fallén, 1819), S. mollis (Becker, 1894), S. tinctinervis (Becker, 1894), Spaziphora hydromyzina (Fallén, 1819), Trichopalpus fraternus (Meigen, 1826), T. (Huckettia) nearcticus (Vockeroth, 1987), T. nigribasis (Curran, 1927), T. obscurellus (Zetterstedt, 1846). Кроме этого, род Acanthocnema Becker, 1894 и Gimnomera lasiostoma впервые отмечена на территории России, а Scathophaga litorea (Fallén, 1819) впервые отмечена на Тихоокенском побережье.

3 вида описаны как новые для науки: Acanthocnema vikhrevi sp.n. из Магаданской области, Cordilura kosterini sp.n. из Приморского края и Cordilura monochroma sp.n. из Приморского края и Сахалинской области. Установлено, что Scathophaga sychevskayae Ozerov, 2010 - новый синоним Scathophaga mollis (Becker, 1894).

\section{Introduction}

The Scathophagidae is a small family of calyptrate Diptera distributed mainly in the Northern Hemisphere. 
The world fauna currently comprises about 400 species. Fauna of Russia includes about 200 species [e.g. Gorodkov, 1986; Ozerov, 1993, 1997, 1999a, 1999b, 2010a, 2010c, 2010e; Ozerov \& Krivosheina, 2012a, 2013b, 2014] in 35-40 genera according to different authors [e.g. Gorodkov, 1970, 1986; Šifner, 2008; Ozerov, 2010b, 2010c; Ozerov \& Krivosheina, 2013a].

26 species were described from the territory of Russian Far East [Becker, 1894; Coquillett, 1901; Hendel, 1930; Stackelberg, 1952; Elberg, 1972; Ozerov, 1993, 1996, 1997, 1999a, 1999b, 2006, 2007a, 2007b, 2010d, 2012, 2013; Engelmark, 1999; Ozerov \& Krivosheina, $2012 b, 2013 b]$, the 7 species of these species are considered to be synonyms [Ozerov, 2007c, 2009a; Ozerov \& Krivosheina, 2013a]. Gorodkov [1986] mentioned 35 species from Russian Far East, but gave the places of collecting not for all of them.

The present work contains the list of 97 species from the territory of Russian Far East, 29 of them are registered for the territory for the first time. Besides, 3 species new to science are described. One new synonym is established: Scathophaga sychevskayae Ozerov, 2010 is a new synonym of Scathophaga mollis (Becker, 1894).

\section{Material and methods}

The majority of specimens examined for this study are deposited in the Zoological Museum, Moscow State University, Russia (ZMUM). We also studied some materials and the type-specimens of species, which were described from the territory of Russian Far East from the following Museums and Institutes: IBSS Institute of Biology and Soil Sciences, Russian Academy of Sciences, Far Eastern Branch, Vladivostok, Russia; ISEA - Institute of Systematics and Ecology of Animals, Russian Academy of Sciences, Siberian Branch, Novosibirsk, Russia; IZBE - Institute of Zoology and Botany, Tartu, Estonia; MZLU — Lund University, Lund, Sweden; NHRS - Naturhistoriska riksmuseet, Stockholm, Sweden; USNM - National Museum of Natural History [formerly United States National Museum], Washington, USA; ZISP — Zoological Institute of Russian Academy of Sciences, St.Petersburg, Russia; ZMB - Museum für Naturkunde der Humboldt-Universität, Berlin, Germany. Also other abbreviations are used: IPEE - A.N. Severtsov Institute of Ecology and Evolution, Russian Academy of Sciences, Moscow; KRE - Kronotskyi Reserve, Elizovo, Kamchatka.

The majority of original Russian labels are given in transliteration, but names of some global geographical regions (e.g. Amur Oblast, Sakhalin Oblast, Khabarovsk Kray, Primorskiy Kray) follows Merriam Webster's Geographical Dictionary [1997]. Geographical coordinates are given in the Decimal Degrees format.

All taxa recognised as valid are listed alphabetically. Besides the names of the species described from the territory of Russian Far East, which proved to be syno- nyms are given also. The names of the Museums and Institutes keeping the types of species described from Russian Far East are given.

The data on the distribution are regulated as follows: Russia is on the first place, the regions of the Far East following it after colon [:], other regions of Russia following it after semicolon [;], other countries of the World are given after dash [-]. More detailed data on the distribution of the species in Europe may be found in the work by Šifner [2008], and in North America in the work by Vockeroth [1965].

The terminology are used for the description of new species follows McAlpine [1981], Cumming et al [2009], and Stuckenberg [1999].

\section{List of species}

Acanthocnema vikhrevi Ozerov et Krivosheina, sp.n. Figs 1-3, 5, 6.

MATERIAL. Holotype $\sigma^{7}$, Russia: Magadan Oblast, Yablonevyy Pass (60.59N 151.53E), 900 m, 16-18.VII.2014, N. Vikhrev (in ZMUM). Paratypes: data as for holotype (2 $\sigma^{\top} \sigma^{7}, 2$ + 2 , in ZMUM); Russia: Magadan Oblast, Sokol env. (59.92N 150.71E), 11-19.VII.2014, N. Vikhrev (1 ऽ', in ZMUM).

DESCRIPTION. Male, female. Body blackish in ground colour and densely grey dusted. Length of body 6.5-7.0 mm. Length of wing 6.6-6.8 $\mathrm{mm}$.

Frontal vitta black, matt; fronto-orbital plate black, grey dusted. 3 orbitals, 3-4 frontals, 1 ocellar, 1 inner vertical, 1 outer vertical (approximately 0.5 times as long as inner vertical); postocellar setae absent or at least not differ from setulae on ocellar triangle. Gena from yellowish to black, with silver reflection, broad, depth below lowest eye-margin almost equal to length of vertical diameter of eye. Vibrissal angle yellow, with 2-3 vibrissae. Face densely white or yellowish dusted. Parafacial yellowish. Postcranium black, grey dusted. Palpus yellow in male and black in female, more broaded in male than in female. Antenna black; postpedicel rounded apically, 2 times as long as broad. Arista pubescent on basal two-thirds and bare apically.

Scutum densely grey dusted, with a patch of brown markings around intra-alar and supra-alar areas. Acrostichal hairs in two rows, dorsocentrals $3+3$ (first presutural weak and directed anteriorly), intra-alars (01) +2 , supra-alars $1+1,2$ postpronotals (the median one weak), 2 notopleurals, 2 postalars. Pleura densely grey dusted, anepisternum brown dusted in upper third. Proepisternum with yellow hairs and 1 seta near ventral margin. Proepimeron with 1 seta ventral to spiracle. Anepisternum with rare hairs in posterior half and 1-2 long setae near posterior margin. Katepisternum with yellow hairs posteriorly and one long seta in posterodorsal corner. Anepimeron bare. Scutellum grey dusted, with pair of strong apical and pair of strong basal setae; lateral margins and dorsal surface apically with black hairs and setulae.

Legs black, densely grey dusted. Fore femur with row of dorsal/posterodorsal setae in both sexes; with 

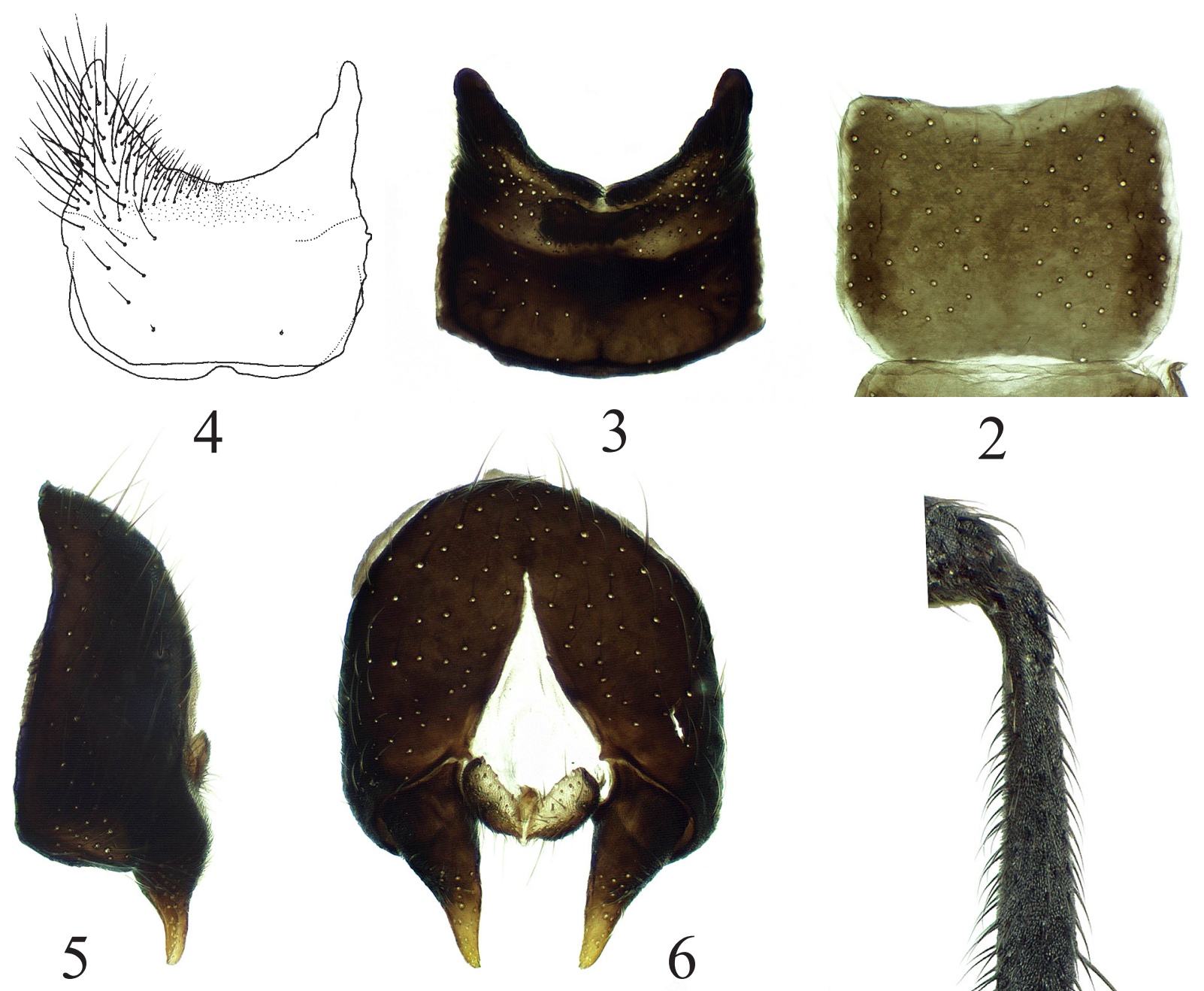

2
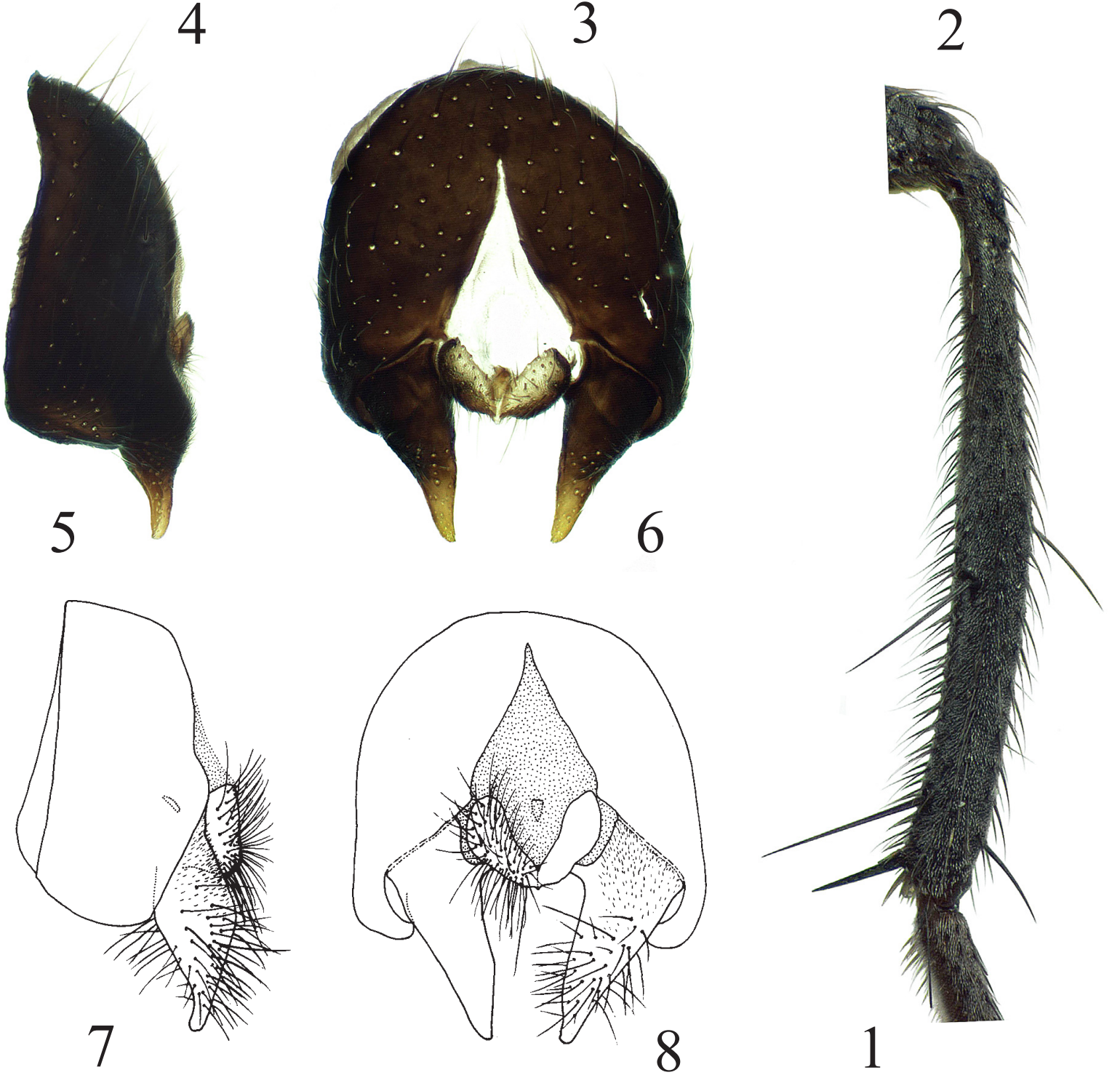

Figs 1-8. Acanthocnema vikhrevi Ozerov et Krivosheina, sp.n., PT $0^{7}(1-3,5-6)$ and Acanthocnema sternalis Suwa, $0^{7}(4,7,8): 1-$ fore right tibia, posterior view; $2-$ sternite $4 ; 3,4-$ sternite $5 ; 5,7$ - epandrium, cerci and surstyli, lateral view; 6,8 - epandrium, cerci and surstyli, dorsal view. 4, 7, 8 - after Suwa, 1986.

Puc. 1-8. Acanthocnema vikhrevi Ozerov et Krivosheina, sp.n., PT O (1-3, 5-6) and Acanthocnema sternalis Suwa, $0^{\top}(4,7,8): 1-$ голень передней правой ноги, сзади; 2 - стернит 4; 3, 4- стернит 5; 5, 7 - эпандрий, церки и сурстили, сбоку; 6,8 - эпандрий, церки и сурстили, сверху. 4, 7, 8 - по Suwa, 1986. 
row of fine long hairs on ventral/anteroventral surface basally in male; with one pale and two black ventral/ anteroventral setae in basal third in female. Fore tibia with ventral apical spur, 1 preapical dorsal, 1 anterodorsal at middle and 1-2 posteroventral setae (Fig. 1 ), without rows of spunules ventrally. Mid femur with row of anterior/anterodorsal setae, with 1 posterodorsal apical and 1-2 posterior apical setae. Mid tibia with 1 anterodorsal and 1 posterior setae at middle, with 1 preapical dorsal seta, and following apical setae: anterior, anteroventral and posteroventral. Hind femur with row of anterodorsal setae, 4-5 dorsal setae in apical half, 3-5 anteroventral setae in apical half, 2-3 usually pale ventral setae in basal half. Hind tibia with $2-3$ anterodorsal, 2 posterodorsal, 1 preapical dorsal setae, also anterior and anteroventral apical setae.

Wing conspicuously blackish tinged; veins black. Calypteres and halter brownish.

Abdomen black, densely grey dusted. Tergites 1-6 with not strong marginal setae except on middle in male, without setae in female. Male sternites 3 and 4 and female sternites 3-6 wider than long. Male sternites 4 and 5 as in Figs 2, 3. Epandrium, cerci and surstyli as in Figs 5, 6.

COMPARISON. New species is closely related to A. sternalis Suwa, 1986, described from Japan (Hokkaido), which also has the broadened sternites especially in female. New species easyly differs from A. sternalis by absence of rows of spunules ventrally on fore tibia, and presence of good visible two postpronotal setae.

ETYMOLOGY. The species is named in gonor of my friend and colleague Nikita E. Vikhrev, who collected the type material of this species.

DISTRIBUTION. Russia: Magadan Oblast.

\section{Acerocnema lobanovi Ozerov, 2006}

The species was described from town Zeya (53.7485N 127.2614E), Amur Oblast and Kamenushka (43.6342N 132.2220E), Primorskiy Kray [Ozerov, 2006: 334]. Holotype and paratypes are kept in ZMUM.

DISTRIBUTION. Russia: Primorskiy Kray.

Allomyella crinipes (Ringdahl, 1928)

MATERIAL EXAMINED. Chukotka: Meynypil'gyno env. (62.5385N 177.0519E), 20.VII.2013, P.S. Tomkovich (1 $\sigma^{\top}, 1$, in ZMUM).

DISTRIBUTION. Russia: Chukotka (first record for Russian Far East); european part of Russia. Europe (Sweden), ?North America.

\section{Allomyella portenkoi Stackelberg, 1952}

This species was described from Aternon-Rogers (70.9832N 178.4166E), Wrangel Island, Chukotka [Stackelberg, 1952: 406]. Holotype is kept in ZISP [Ozerov \& Krivosheina, 2013a].

DISTRIBUTION. Russia: Chukotka (Wrangel I.).

\section{Cleigastra apicalis (Meigen, 1826)}

MATERIAL EXAMINED. Magadan Oblast: Sokol env. (59.92N 150.71E), 11-19.VII.2014, N. Vikhrev (1 $\sigma^{7}$, in ZMUM); Kamchatka Kray: Zhupanovo (54.0822N 159.9811E), 2.VII.1988, L. Lobkova (1 $\sigma^{\prime}$, in ZMUM); Paratunka (52.9602N 158.2486E), 8.VII.1984, N. Krivosheina (1 9 , in ZMUM); Uzon (54.4877N 159.9772E), Komariny creek floodplain, 11.VII.1987, L. Lobkova $\left(1 O^{7}\right.$, in ZMUM); Khabarovsk Kray: Kirpichnyy Stream (49.261 N 140.33E), 11.VI.2014, N. Vikhrev (1 $\sigma^{7}$, in ZMUM); Chistovodnaya River (49.10N 139.83E), 460 m, 10.VI.2014, N. Vikhrev (1 o, in ZMUM).

DISTRIBUTION. Russia: Magadan Oblast, Kamchatka Kray, Khabarovsk Kray (first record for Russian Far East); european part of Russia, Siberia. Europe, Asia (Iraq, Mongolia).

\section{Cleigastra sundukovi Ozerov, 2013}

Described from Tserkovnaya Bay (43.75N 146.70E), Shikotan I., Kuril Islands [Ozerov, 2013: 85]. Holotype is kept in ZMUM.

MATERIAL EXAMINED. Sakhalin Oblast: Kuril Islands, Kunashir I., Ivanovskyi Cape (43.828N 145.400E), 23-29.V.2013, Yu. Sundukov (1 $\sigma^{7}$, in ZMUM).

DISTRIBUTION. Russia: Sakhalin Oblast (Kuril Is.).

\section{Cordilura aberrans (Becker, 1894)}

The species was registered for the Far East by Gorodkov [1986: 14] without specifying the place of collecting.

MATERIAL EXAMINED. Amur Oblast: Khorogochi River (55.8331N 124.6608E), 2.VII.1975, Soboleva (3 90 , in IBSS); Nukzha River (56.5741N 121.6527E), 18.VI.1976, Soboleva (1 O", in IBSS); town Zeya (53.7485N 127.2614E), 6-21.VI.1978, 1624.VII.1981, A. Ozerov, A. Shatalkin (16 ○ $\sigma^{7}, 10$ 우, in ZMUM); Chukotka: lower reaches of the Anadyr River (64.83N 175.96E), 27-30.VII.2013, A. Barkalov (3 $\sigma^{7} \sigma^{7}$, in ZMUM and ISEA); Khabarovsk Kray: Komsomol'sk-na-Amure, Silinsky Park (50.5736N 137.0392E), 29.V.1985, Mutin (1 ㅇ, in IBSS); Magadan Oblast: Sokol env. (59.92N 150.71E), 11-19.VII.2014, N. Vikhrev ( $1 \overbrace{}^{\top}, 2$ 우, in ZMUM).

DISTRIBUTION. Russia: Amur Oblast, Chukotka, Khabarovsk Kray, Magadan Oblast; european part of Russia, Siberia. - Europe (Scandinavia), Asia (Mongolia).

Cordilura aemula (Collín, 1958)

MATERIAL EXAMINED. Amur Oblast: town Zeya (53.7485N 127.2614E), 12 and 14.VI.1932, Pereleshina (2 $\bigcirc^{7} \sigma^{7}$, in ZMUM); Kamchatka Kray: Kozyrevsk (52.0492N 158.8662E), 27.VI.1984, N. Krivosheina ( 1 , in ZMUM); Khabarovsk Kray: Khabarovsk (48.4874N 135.0767E), 15.VI.1925 (1 ○', in ZMUM); Primorskiy Kray: Novoselskoe (44.7730N 132.6991E), 28.VI.1985, Makarkin (1 $\bigcirc^{7}$, in IBSS).

DISTRIBUTION. Russia: Amur Oblast, Kamchatka and Primorskiy Kray (first record for Russian Far East). - Europe (Great Britain, Estonia).

\section{Cordilura albipes (Fallén, 1819)}

The species was firstly registered for the Far East by Ozerov [2009b: 379] from Lazovsky Reserve, Primorskiy Kray. 
MATERIAL EXAMINED. Amur Oblast: town Zeya (53.7485N 127.2614E), 23.VII. and 1.VIII.1979, 1.VIII. and 310.IX.1981, A. Shatalkin (7 $\bigcirc^{7} \sigma^{7}, 8$ 우, in ZMUM); Zeyskiy Reserve, "52 km" Cordon (54.0873N 126.8713E), 4 and 31.VII.1982, A. Shatalkin ( $\sigma^{\top}, 1$, in ZMUM); Magadan Oblast: Sokol env. (59.92N 150.71E), 11-19.VII.2014, N. Vikhrev (4 $\sigma^{7} \sigma^{7}, 1$ ㅇ, in ZMUM); Primorskiy Kray: Kamenushka (43.6342N 132.2220E), 18.VIII., 5-7.IX.1983, 23.VII. and 8-19.VIII.1984, 14-27.VIII., 2-21.IX.1987, A. Shatalkin, A. Antropov, A.L. Ozerov (5 $0^{7} \sigma^{7}, 19$ + , in ZMUM); Kedrovaya Pad' Reserve (43.1047N 131.5122E), 27.VIII.1980, 18.VII. and 5.IX.1984, A. Shatalkin, S. Churkin (2 $\sigma^{\top} \sigma^{\top}, 3$ 오, in ZMUM); Kievka (42.9047N 133.7013E), 3.IX.1980, A. Shatalkin ( $1 \sigma^{7}$, in ZMUM); Gorno-Taezhnaya Station (43.6936N 132.1525E), 26.IX.1980, A. Shatalkin (1 9 , in ZMUM); Sudzuchinskiy [=Lazovskiy] Reserve, Tachingou (43.0236N 134.1363E), 20.IX.1948, Gussakovskiy ( 1 , in ZMUM); the upper reaches of the Maykhe River [= Artemovka River] (43.6995N 132.5433E), 20.VI.1929, N. Filippov ( 1 , in ZMUM).

DISTRIBUTION. Russia: Amur Oblast, Magadan Oblast, Primorskiy Kray; european part of Russia, Siberia. - Europe (widespread), Asia (Mongolia).

\section{Cordilura amurensis Ozerov, 2007}

The species was described from town Zeya $(53.7485 \mathrm{~N}$ 127.2614E), Amur Oblast [Ozerov, 2007a: 123]. Holotype is kept in ZMUM.

MATERIAL EXAMINED. Khabarovsk Kray: Khicha River (49.05N 139.43E), $690 \mathrm{~m}, 10$. VI.2014, N. Vikhrev (1 +, in ZMUM)

DISTRIBUTION. Russia: Amur Oblast, Khabarovsk Kray.

\section{Cordilura atrata (Zetterstedt, 1846)}

MATERIAL EXAMINED. Chukotka: Meynypil'gyno env. (62.567N 177.033E), 5-20.VI.2009, 1-13.VII.2011, P.S. Tomkovich (7 $O^{7} \sigma^{7}$, in ZMUM); Meynypil'gyno env. (62.5385N 177.0519E), 26-29.VI.2012, 9.VII.2013, P.S. Tomkovich (2 $0^{7} 0^{7}, 1$ 9 , in ZMUM); Kamchatka Kray: Zhupanovo (54.0822N 159.9811E), 2.VII.1988, L. Lobkova, (1 $\sigma^{7}$, in ZMUM); Uzon (54.5033N 159.9900E),

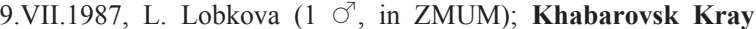
Kirpichnyy Stream (49.261N 140.33E), 11.VI.2014, N. Vikhrev (1 $\sigma^{7}, 1$, in ZMUM); Magadan Oblast: Palatka (60.09N 150.93E), 17.VII.2014, N. Vikhrev (1 O', in ZMUM).

DISTRIBUTION. Russia: Chukotka and Kamchatka Kray, Khabarovsk Kray, Magadan Oblast (first record for Russian Far East); european part of Russia, Siberia. - Europe, North America.

\section{Cordilura bicoloripes Ozerov, 1997}

The species was described from Primorskiy Kray [Ozerov, 1997: 1424], holotype in ZMUM.

MATERIAL EXAMINED. Primorskiy Kray: Kedrovaya Pad' Reserve (43.1047N 131.5122E), 29.VIII.1984 and 3.IX.1984, S Churkin, A. Shatalkin ( 2 +⿱, in ZMUM).

DISTRIBUTION. Russia: Primorskiy Kray [Ozerov, 2009b].

\section{Cordilura fulvifrons Ozerov, 1997}

This species was described from Boitsovo (46.9823N 134.3246E), Khabarovsk Kray [Ozerov, 1997: 1427]. Holotype in ZMB [Ozerov, 2014].

DISTRIBUTION. Russia: Khabarovsk Kray.

\section{Cordilura fuscipes (Zetterstedt, 1838)}

apicata Hendel, 1930: 4 (Cordylura). Synonymized by Ozerov [2007c: 6]. Lectotype of this species designated by Ozerov [2007c], is kept in NHRS.

nigrithorax Hendel, 1930: 5 (Cordylura). Synonymized by Ozerov [2007c: 7]. Holotype of this species is kept in NHRS [Ozerov, 2007c].

ochracea Hendel, 1930: 6 (Cordylura, subgen. Parallelom$m a$ ). Synonymized by Ozerov [2007c: 7]. Holotype of this species is kept in NHRS [Ozerov, 2007c].

The species was firstly registered for the Far East by Hendel [1930 : 4, as Cordylura apicata] from Kamchatka Kray.

MATERIAL EXAMINED. Chukotka: lower reaches of the Anadyr River (64.83N 175.96E), 27-30.VII.2013, A. Barkalov (7 $\mathrm{O}^{7} \mathrm{O}^{7}, 5$ +9 , in ZMUM and ISEA); Kamchatka Kray: Karaginskiy I. $(58.883 \mathrm{~N} 163.833 \mathrm{E})$, mouth of the Giunvayam River, 2526.VII.2008, O.A. Khruleva (1 9 , in IBSS); Uzon (54.5033N 159.9900E), 12 and 16.VII.1977, Stenchenko (2 우, in ZMUM); Vestnik Bay (51.4823N 157.5301E), 27.VII.1999, A. Leley, S. Storozhenko ( 1 , in ZMUM); Avachinskiy Volkano $(53.2550 \mathrm{~N}$ 158.8300E), 27.VII.1985, Belokobyl'skiy (1 $\sigma^{7}$, in ZISP); Khabarovsk Kray: Vanino (49.11N 140.31E), 9.VI.2014, N. Vikhrev ( $1 \mathrm{O}^{7}$, in ZMUM); Magadan Oblast: $(59.5682 \mathrm{~N}$ 150.8091E), 18.VI.1963, Zhelokhovtsev (1 $\sigma^{7}$, in ZMUM); Sokol

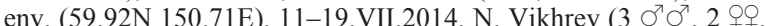
in ZMUM); Donyshko River (60.41N 151.52E), 17.VII.2014, N. Vikhrev (2 $\sigma^{7} \sigma^{7}$, in ZMUM); Palatka $(60.09 \mathrm{~N} 150.93 \mathrm{E})$, 17.VII.2014, N. Vikhrev (1 9 , in ZMUM).

DISTRIBUTION. Russia: Chukotka, Kamchatka Kray, Khabarovsk Kray, Magadan Oblast; european part of Russia, Siberia. - Europe, North America.

\section{Cordilura kakaberrans Ozerov, 1997}

The species was described from Primorskiy Kray [Ozerov, 1997: 1424], holotype in ZMUM.

MATERIAL EXAMINED. Khabarovsk Kray: Kirpichnyy Stream (49.261N 140.33E), 11.VI.2014, N. Vikhrev (1 $\sigma^{7}$, in ZMUM); Taunga River (49.289N 138.594E), 600 m, 12.VI.2014, N. Vikhrev (1 $\sigma^{7}$, in ZMUM); Khicha River (49.05N 139.43E), 690 m, 10.VI.2014, N. Vikhrev (1 $\circ$, in ZMUM); Primorskiy Kray: Spassk (44.6000N 132.8166E), 19.VII.1961, Zhelokhovtsev $(1$, in ZMUM).

DISTRIBUTION. Russia: Khabarovsk Kray, Primorskiy Kray.

\section{Cordilura krocha Ozerov, 2007}

This species was described from town Zeya (53.7485N 127.2614E), Amur Oblast [Ozerov, 2007a: 123]. Holotype is kept in ZMUM.

DISTRIBUTION. Russia: Amur Oblast.

\section{Cordilura kosterini Ozerov et Krivosheina, sp.n.} Figs 9-12.

MATERIAL. Holotype $\sigma^{7}$, Russia: Primorskiy Kray: Lotos Lake (42.46N 130.64E), 1-3.VII.2014, O. Kosterin (in ZMUM). The specimen was collected on leaves of Nelumbo nucifera Gaertner, 1788 (Nelumbonaceae).

DESCRIPTION. Male. Length of body $6.6 \mathrm{~mm}$. Length of wing $5.6 \mathrm{~mm}$.

Frontal vitta and fronto-orbital plate black, whitish microtrichose. Face white, with silver reflection. Ocel- 


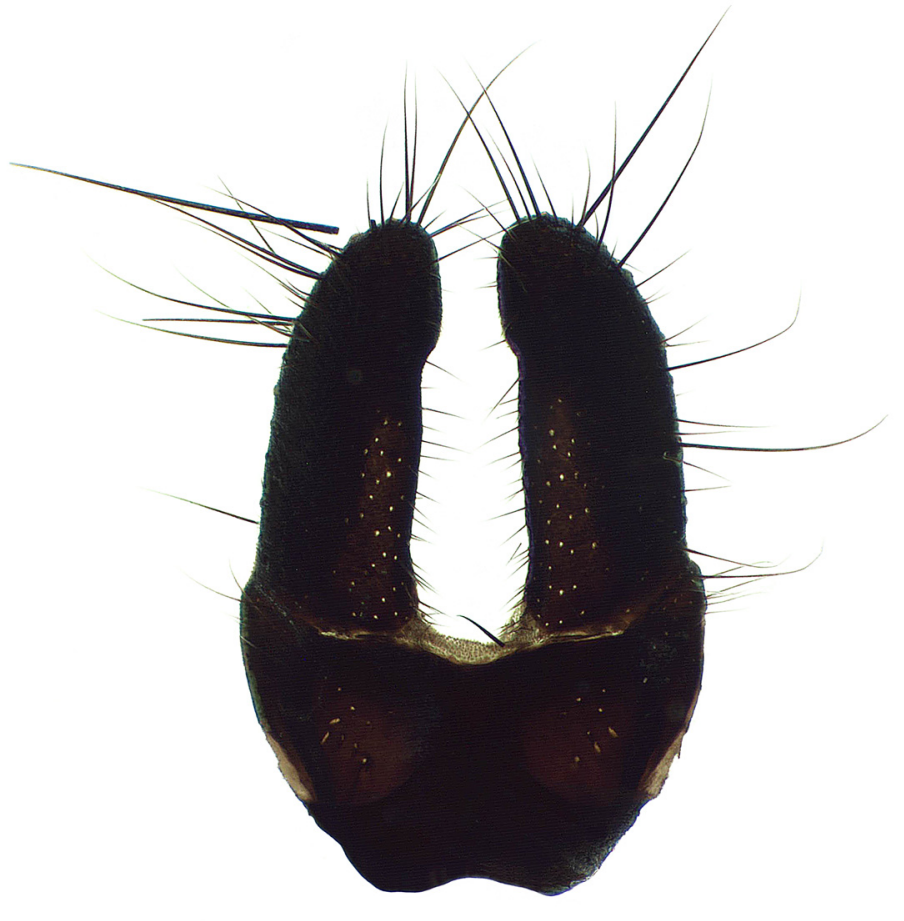

10
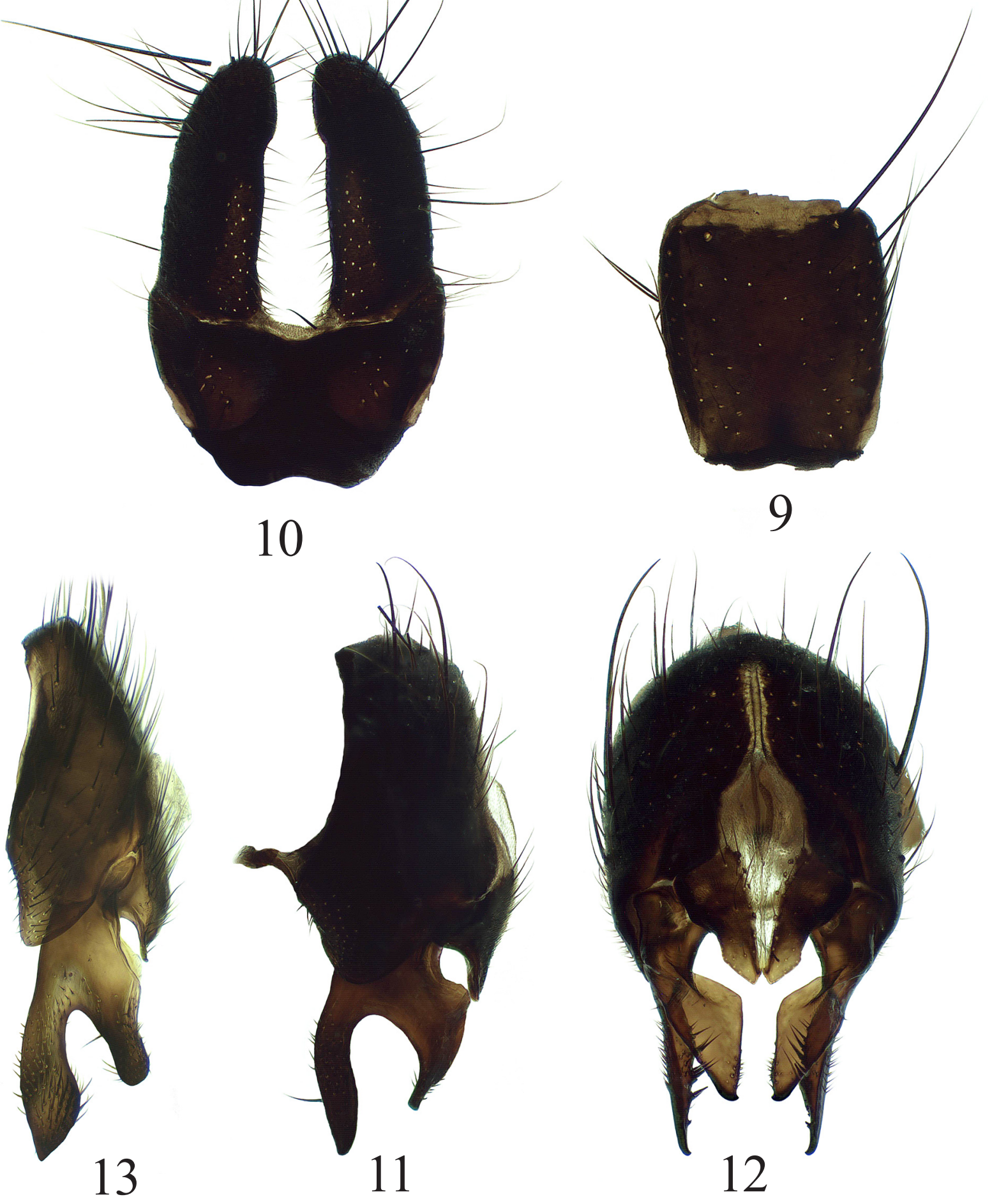

Figs 9-13. Cordilura impudica (Rondani), $\sigma^{7}$ (13) and Cordilura kosterini Ozerov et Krivosheina, sp.n., HT $\sigma^{7}$ (9-12): $9-$ sternite 4; 10 - sternite 5; 11, 13 - epandrium, cerci and surstyli, lateral view; 12 - epandrium, cerci and surstyli, dorsal view.

Рис. 9-13. Cordilura impudica (Rondani), О (13) и Cordilura kosterini Ozerov et Krivosheina, sp.n., HT ${ }^{7}$ (9-12): 9 стернит 4; 10 - стернит 5; 11, 13 - эпандрий, церки и сурстили, сбоку; 12 - эпандрий, церки и сурстили, сверху. 
lar triangle black. Gena black, with silver reflection. Postcranium black. 3 orbitals, 3-4 frontals, 1 ocellar, 1 very long inner vertical, 1 outer vertical (approximately 0.5 times as long as inner vertical), 1 small postocellar setae present; 1 pair of strong vibrissae and 1 pair of subvibrissae present. Antenna black. First flagellomere rounded apically, approximately 2 times as long as wide. Arista black, plumose. Palpus, clypeus and proboscis black. Palpus with long apical seta.

Thorax black, whitish microtrichose. Acrostichal hairs absent, dorsocentrals $3+3$ (first presutural directed anteriorly), intra-alars $(0-1)+2$, supra-alars $1+2,2$ postpronotals, 2 notopleurals, 2 postalars. Proepisternum with yellow hairs and 2 black setae near ventral margin. Proepimeron with 1 black seta ventral to spiracle. Anepisternum with rare yellow hairs in posterior half and 3-4 black setae near posterior margin. Katepisternum with yellow hairs posteriorly and one long black seta in posterodorsal corner. Anepimeron bare. Scutellum with one pair of strong basal setae.

Coxae, trochanters and fore femora of all legs black; tibiae of fore and mid legs and tarsi of all legs yellow; hind tibia yellow, but darkened dorsally.

Fore femur with row of anterodorsal setae, row of thin and long ventral setae, and with fine long hairs on posterior and posteroventral surfaces. Fore tibia with 2 dorsal, 1 posterior, and 2 posteroventral setae, and with ring of apical setae. Mid femur with rows of anterior and anterodorsal setae and with 2 posterior apical setae. Mid tibia with 2 anterodorsal, 2 posterodorsal, 1-2 anteroventral, and 2 thin and long posterior setae, and with ring of apical setae. Hind femur with rows of anterodorsal and anteroventral setae, 2 dorsal setae in apical half, and 1 posterior apical seta. Hind tibia with 3 anterodorsal, 3 posterodorsal, 2 anterior, and ring of apical setae.

Wing tinged with brownish; veins brown. Calypteres, including margins, and halteres yellowish.

Abdomen long, cylindrical, black (dissected and moved in microvial tube). Tergites grey dusted. Syntergite 1+2 with 2-3 lateral discal and 2-4 lateral marginal setae; tergites 3-6 each with a row of marginal setae. Male sternites 4 and 5 as in Figs 9, 10. Epandrium, cerci and surstyli as in Figs 11, 12.

Female unknown.

COMPARISON. New species is closely related to Palaearctic species C. impudica (Rondani, 1867), but is distinguished from this species by structure of surstylus (Figs 11 and 13).

ETYMOLOGY. The species is named after Oleg Kosterin (Novosibirsk), the collector of the holotype specimen.

DISTRIBUTION. Russia: Primorskiy Kray.

Cordilura monochroma Ozerov et Krivosheina, sp.n. Figs 16-19.

MATERIAL. Holotype $\sigma^{7}$, Russia: Sakhalin Oblast, Kuril Islands, Kunashir I., Yuzhno-Kurilsk (43.026N 145.862E), 6.VII.2013, leg. Yu. Sundukov (in ZMUM). The holotype is pinned and in excellent condition. Paratypes: Russia: Primorskiy Kray: Kamenushka (43.6342N 132.2220E), 14.VII.1983, A. Shatalkin
(1 $\sigma^{7}$, in ZMUM); Sakhalin Oblast: Kuril Islands, Shikotan I. Tserkovnaya Bay (43.75N 146.70E), 27-31.VIII.2012, Yu. Sundukov (1 $\sigma^{7}$, in ZMUM); Sakhalin Oblast, Kuril Islands, Kunashir I., Cape Ivanovskyi (43.828N 145.400E), 13.VII.2013, leg. Yu. Sundukov (1 $\sigma^{7}$, in ZMUM).

DESCRIPTION. Male. Length of body $6.8 \mathrm{~mm}$. Length of wing $5.2 \mathrm{~mm}$.

Frontal vitta yellow, with silver reflection; frontoorbital plate black, whitish microtrichose. Ocellar triangle black. Face and parafacial yellow. Gena from yellow to black. Postcranium black, whitish microtrichose. 3 orbitals, 3 frontals, 1 ocellar, 1 very long inner vertical, 1 outer vertical (approximately 0.5 times as long as inner vertical), 1 small postocellar; 1 pair of strong vibrissae and 1-2 pairs of subvibrissae present. Antenna black. First flagellomere rounded apically, approximately 2 times as long as wide. Arista black, plumose. Palpus, clypeus and proboscis black. Palpus with long apical seta.

Thorax black, whitish microtrichose. Acrostichal hairs in two rows, 2-3 pairs of presutural and 1 pair of postsutural (prescutellar); dorsocentrals $3+3$ (first presutural directed anteriorly), intra-alars 1+2, supraalars $1+2,2$ postpronotals, 2 notopleurals, 2 postalars. Proepisternum with yellow hairs and 1 black seta near ventral margin. Proepimeron with 1 black seta ventral to spiracle. Anepisternum with rarely yellow hairs in posterior half and 3-4 black setae near posterior margin. Katepisternum with yellow hairs posteriorly and 1 long black seta in posterodorsal corner. Anepimeron bare. Scutellum with 2 pairs of strong setae (basal and apical).

Coxae and fore femora of all legs black; tibiae of fore and mid legs yellow, tibia of hind leg from yellow to black; trasi of all legs brownish or blackish, ventral surface of fore tarsus uniform brownish (Fig. 14). Fore femur with rows of dorsal and dorsoventral setae, and with fine long hairs on posterior and posteroventral surfaces. Fore tibia with 2 dorsal, 1 posterior, and 2 posteroventral setae, with long hairs on ventral surface, and with ring of apical setae. Mid femur with row of anterior setae and with 2 posterior apical setae. Mid tibia with 2 anterodorsal and 2 posterodorsal setae, with 1 short anteroventral setula at middle, with row of thin and long posterior setae, and with ring of apical setae. Hind femur with row of anterodorsal setae, 3-4 dorsal setae in apical half, and 1 posterodorsal apical seta. Hind tibia with 3-5 dorsal, 3 anterior, 2-3 anteroventral, and ring of apical setae.

Wing tinged with brownish; veins brown. Calypteres, including margins, and halteres whitish.

Abdomen long, cylindrical; ground colour black. Tergites densely grey dusted. Syntergite $1+2$ with 3-4 lateral discal and 2-4 lateral marginal setae; tergites 3-6 each with a row of marginal setae. Male sternite 5 as in Fig 16. Epandrium, cerci and surstyli as in Figs 18 and 19.

Female unknown.

COMPARISON. New species is closely related to Palaearctic species C. rufipes (Meigen, 1826), but is readily distinguished from this species by the absence 

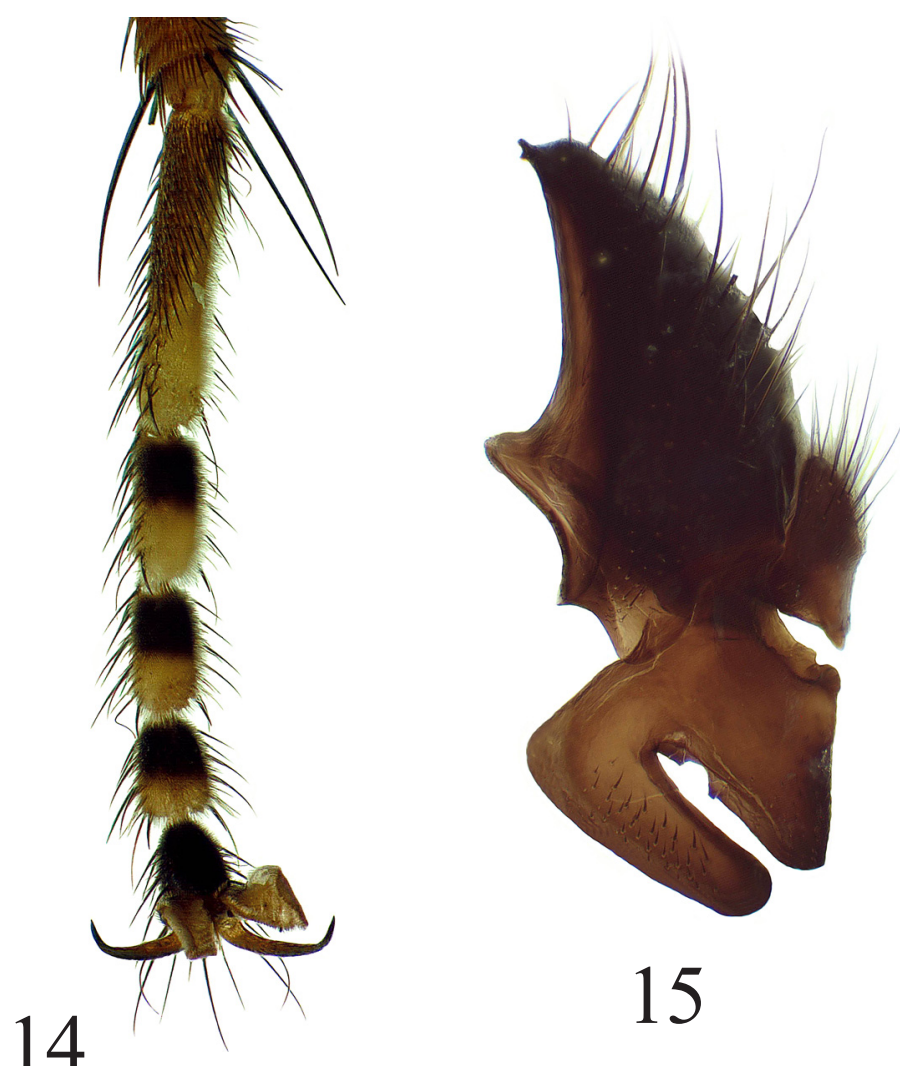

15

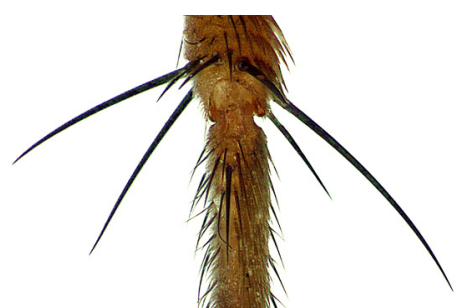

17

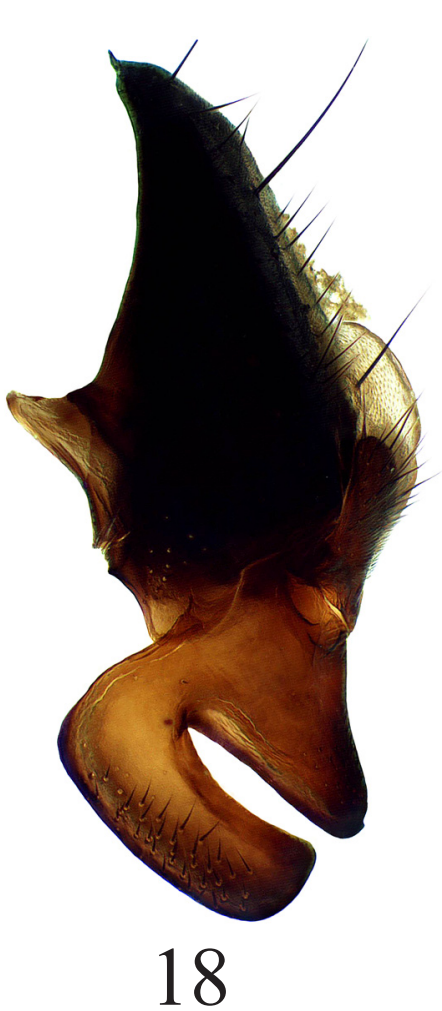

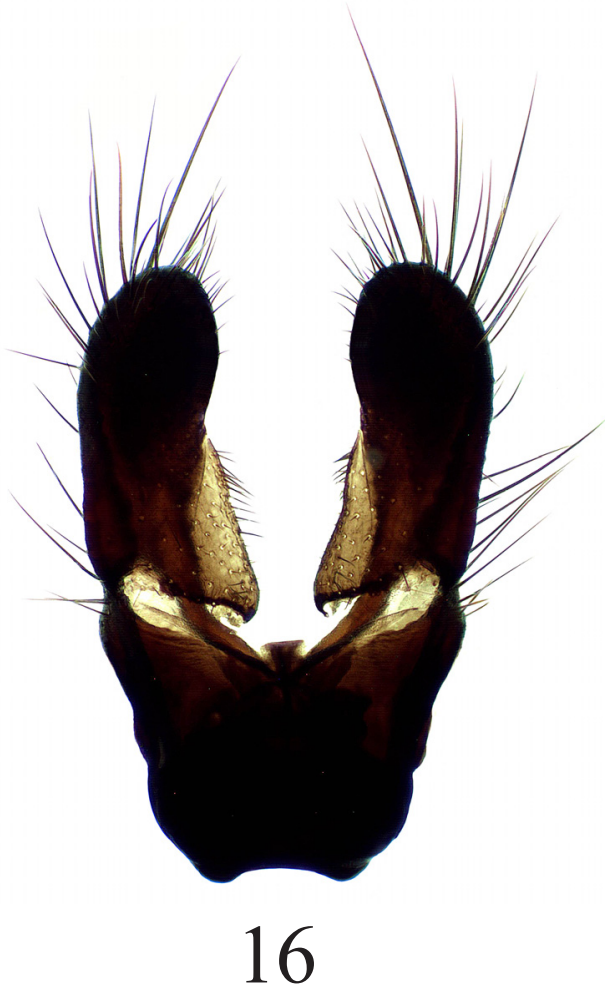

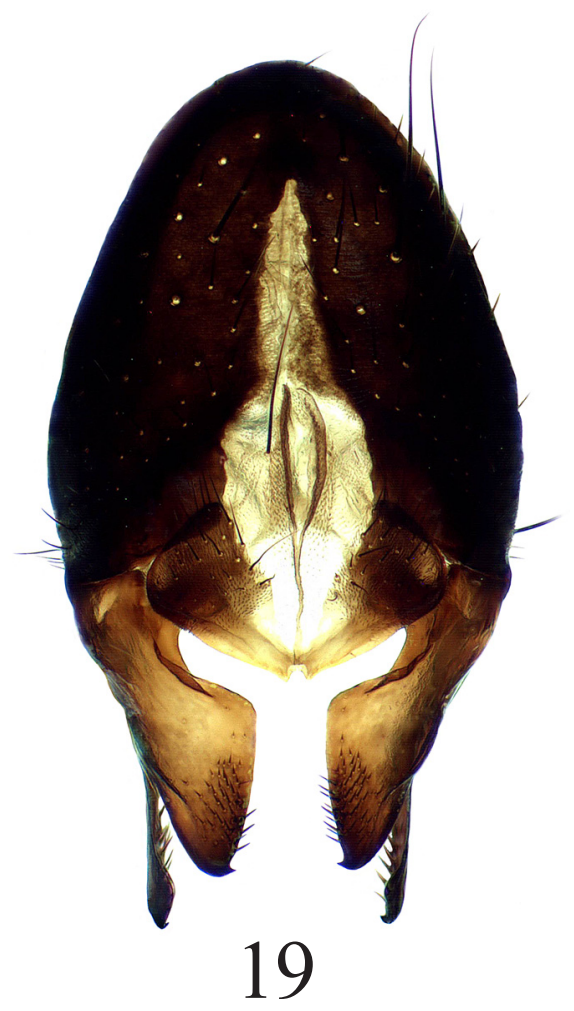

Figs 14-19. Cordilura rufipes (Meigen), $0^{7}(14,15)$ and Cordilura monochroma Ozerov et Krivosheina, sp.n., PT $0^{7}(16-19): 14,17$ tarsus, ventral view; 15,18 - epandrium, cerci and surstyli, lateral view; 16 - sternite 5; 19 - epandrium, cerci and surstyli, dorsal view.

Рис. 14-19. Cordilura rufipes (Meigen), о $(14,15)$ и Cordilura monochroma Ozerov et Krivosheina, sp.n., РТ О (16-19): 14, 17 лапка, снизу; 15,18 - эпандрий, церки и сурстили, сбоку; 16 - стернит 5; 19 - эпандрий, церки и сурстили, сверху. 
of black spots on tarsi dorsally (Figs 17 and 14). Besides, C. rufipes has more narrowed lobe of surstylus (Figs 15 and 18).

DISTRIBUTION. Russia: Primorskiy Kray, Sakhalin Oblast (Kuril Islands).

\section{Cordilura nubecula (Sasakawa, 1986)}

The species was firstly registered for the Far East by Ozerov \& Krivosheina [2012b: 4] from Khabarovsk Kray.

DISTRIBUTION. Russia: Khabarovsk Kray. Asia (Japan [Sasakawa, 1986]).

\section{Cordilura picticornis (Loew, 1864)}

latigenis Hendel, 1930: 3 (Cordylura). Synonymized by Ozerov [2007c: 7]. Lectotype of this species designated by Ozerov [2007c: 7], is kept in NHRS.

The species was firstly registered for the Far East by Hendel [1930: 3, as Cordylura latigenis] from Kamchatka Kray.

MATERIAL EXAMINED. Chukotka: lower reaches of the Anadyr River (64.83N 175.96E), 5 m., 18 and 29.VII., 8.VIII.2013, A. Barkalov (3 우, in ISEA); Kamchatka Kray: Uzon $(54.5033 \mathrm{~N} 159.9900 \mathrm{E}$, 54.4877N 159.9772E), 16 and 17.VII., 1.VIII.1977, Stenchenko (1 $\mathrm{O}^{7}$, 2 우, in ZMUM), 11.VII.1987, 20.VII.2009, L. Lobkova (2 O' $\mathrm{O}^{7}, 3$ 우, in ZMUM); Magadan Oblast: (59.5682N 150.8091E), 27.VII.1963, Zhelokhovtsev (1 9 , in ZMUM); Sokol env. (59.92N 150.71E), 11-19.VII.2014, N. Vikhrev (1 O $^{\top} \mathrm{O}^{\prime}, 2$ 우, in ZMUM).

DISTRIBUTION. Russia: Chukotka, Kamchatka Kray, Magadan Oblast; european part of Russia, Siberia. - Europe (Great Britain, Scandinavia), North America.

Cordilura pudica (Meigen, 1826)

MATERIAL EXAMINED. Amur Oblast: town Zeya (53.7485N 127.2614E), 10-17.VI.1978, 12.VIII.1982, A. Shatalkin, A.L. Ozerov (3 $\mathrm{O}^{7} \mathrm{O}^{\top}, 3$, +9 , in ZMUM); Primorskiy Kray: Khasan env. (42.4245N 130.6511E), 13.VIII.1962, L. Zimina ( ${ }^{\circ}$, in ZMUM); Spassk (44.6000N 132.8166E), 6.VI.1961, Zhelokhovtsev (1 9 , in ZMUM); Sakhalin Oblast: Kunashir I., Mendeleev Volkano env. (43.9610N 145.7290E), 21.VI.1985, S. Churkin (1 , in ZMUM)

DISTRIBUTION. Russia: Amur Oblast, Primorskiy Kray, Sakhalin Oblast (first record for Russian Far East); european part of Russia, Siberia. - Europe (widespread), Asia (China [Sun, 1996]), North America.

\section{Cordilura remmi Elberg, 1972}

This species was described on material from Amur and Sakhalin Oblast, Khabarovsk and Primorskiy Kray [Elberg, 1972: 91]. Holotype is kept in IZBE.

MATERIAL EXAMINED. Amur Oblast: Blagoveshchensk $(50.2805 \mathrm{~N} 127.5350 \mathrm{E}), 17$. VIII.1982, A. Leley (1 ㅇ, in ZISP); Nukzha River (56.5741N 121.6527E), 18.VI.1976, Soboleva (2 우, in IBSS); Komsomol'sk-na-Amure, Silinsky Park (50.5736N 137.0392E), 29.V.1985, Mutin (1 9 , in IBSS); town Zeya (53.7485N 127.2614E), 26.VI., 3-12.VII.1978, 16-20.VII., 313.VIII., 1.IX.1981, 14.VIII.1982, A. Ozerov, A. Shatalkin (14 $0^{7} \mathrm{O}^{7}, 16$ 우, in ZMUM); Zeyskiy Reserve, "34 km" Cordon (53.9899N 127.0735E), 24.-30.VII.1981, 10 and 21.VII.1982, A.L.
Ozerov, A. Shatalkin, M. Krivosheina, O. Gorbunov (3 $0^{7} 0^{7}, 7$ 우, in ZMUM); Zeyskiy Reserve, "52 km" Cordon $(54.0873 \mathrm{~N}$ 126.8713E), 24.VIII.1981, 12.VIII.1982, A.L. Ozerov, A. Shatalkin $\left(1 \mathrm{O}^{7}, 2\right.$ 우, in ZMUM); 5-6 km above of Ekimchan (53.0853N 132.9742E), 23.VIII.2006, A.B. Ryvkin (1 9 , in ZMUM); Jewish Autonomus Oblast: Malyy Khingan Ridge, Dichun River (48.5459N 130.7603E), 15.VII.1979, A. Shatalkin (1 O', in ZMUM); Khabarovsk Kray: Khabarovsk $(48.4874 \mathrm{~N} 135.0767 \mathrm{E})$, 17.VI.1931, V. Pereleshina ( $\sigma^{7}, 1$, in ZMUM); Taunga River (49.289N 138.594E), $600 \mathrm{~m}, 12 . \mathrm{VI} .2014, \mathrm{~N}$. Vikhrev (1 $\mathrm{O}^{7}$, in ZMUM); Khabarovsk (48.6N 135.1E), 13.VI.2014, N. Vikhrev (1 9 , in ZMUM); Primorskiy Kray: $30 \mathrm{~km} \mathrm{~S}$ of Lazo, Benevskoe (43.1667N 133.7578E), 16.VIII.1986, A. Leley (1 O', in ZISP); 5 $\mathrm{km} \mathrm{S}$ of Yakovlevka (44.4275N 133.4794E), 29.VI.-1.VII.1986, A. Leley $\left(1 \sigma^{7}, 2\right.$ 우, in IBSS); Vladivostok, Marine cemetery $(43.0839 \mathrm{~N} 131.9347 \mathrm{E}), 13$. VIII.1993, Belokobyl'skiy $\left(1 \mathrm{O}^{7}\right.$, in ZISP); Gorno-Taezhnaya Station, Krivoy klyuch $(43.6936 \mathrm{~N}$ 132.1525E), 30.VII. and 26.VIII.1980, M. Mikhaylovskaya (2 $0^{7} \sigma^{7}$, in IBSS); Dal'nerechensk 2 (45.9263N 133.7401E), 25.VII.1980, M. Mikhaylovskaya $\left(1 \sigma^{7}\right.$, in IBSS); Kamenushka $(43.6342 \mathrm{~N}$ 132.2220E), 21-30.VII., 19-20.VIII.1983, 25.VII., 4-26.VIII.1984, 4 and 17.VI.1985, 14-16.VII.1986, 9-26.VIII., 1-15.IX.1987, 31.VIII.-3.IX.1988, 19.VIII.1989, A. Antropov, A.L. Ozerov, A. Shatalkin, S. Churkin (21 $\sigma^{7} \sigma^{7}, 15$ 우, in ZMUM), 7.VII. and 13.VIII.1981, Mutin, Belova (1 $\sigma^{7}, 1$ \%, in IBSS); Kedrovaya Pad' Reserve (43.1047N 131.5122E), 22.VIII.1982, Romanova (1 + , in ZISP), 29.VIII.1978, D. Shcherbakov (1 $0^{7}$, in ZMUM); Kievka $(42.9047 \mathrm{~N} 133.7013 \mathrm{E}), 2 . \mathrm{IX} .1980$, A. Shatalkin (1 9 , in ZMUM); Lazovskiy Reserve, $10 \mathrm{~km} \mathrm{~W}$ of Preobrazhenie (42.9123N 133.7749E), 16.VIII.1986, A. Leley (1 $\sigma^{7}$, in ZISP); Bikin River, $22 \mathrm{~km}$ above mouth of the Svetlovodnaya River $(46.6166 \mathrm{~N}$ 137.0543E), 14.VIII.1980, V. Zlobin (2 OP, in ZISP); Bol'shaya Ussurka River, $20 \mathrm{~km} \mathrm{NW}$ of Mel'nichnoe (45.5485N 135.3476E), 2.VIII.1986, A. Leley (3 우, in IBSS); Spassk $(44.6000 \mathrm{~N}$ 132.8166E), 6-17.VI., 3-10.VII.1961, Zhelokhovtsev (1 O', 4 우, in ZMUM); Suvorovo (44.2483N 135.3473E), 17.VII.1972, A. Ponomarenko (1 $\sigma^{7}$, in ZMUM); Sudzuchinskiy [=Lazovskiy] Reserve, Tachingou (43.0236N 134.1363E), 23.VIII., 6.IX.1948, Gussakovskiy (2 OO9, in ZMUM); Andreevka (ca. 42.64N 131.13E), 25-30.VI.2014, N. Vikhrev (1 $\mathrm{O}^{7}$, in ZMUM); Anuchino env. (43.95N 133.05E), 20-21.VI.2014, N. Vikhrev (1 +, in ZMUM); Kamenushka (43.62N 132.23E), 22-24.VI.2014, N. Vikhrev (1 9 , in ZMUM); Sakhalin Oblast: Kunashir I., $7 \mathrm{~km} \mathrm{~S}$ of Mendeleevo (44.0231N 145.6807E), 22.VIII.1975, Berezantsev (1 9 , in IBSS); Kunashir I., $7 \mathrm{~km} \mathrm{~S}$ of Lagunnoe Lake (44.0010N 145.7605E), 12 and 15.VIII.1989, Leley, Sidorenko (1 $\mathrm{O}^{7}, 1$, in IBSS); Kunashir I., caldera of Golovnin Volkano (43.8438N 145.5050E), 3.VIII.1989, Sidorenko (1 $\sigma^{7}, 1$, in IBSS); Kunashir I., Stolbchatyy Cape (44.0236N 145.6794E), 28.VII.1989, Sidorenko (1 $\sigma^{7}$, in IBSS); Kuril Islands, Kunashir I., Yuzhno-Kuril'sk env. (44.0297N 145.8605E), 18-19.VIII.1989, Leley, Sidorenko (1 $\sigma^{7}, 1$, in IBSS); Kuril Islands, Shikotan I. Tserkovnaya Bay $(43.75 \mathrm{~N}$ 146.70E), 10-30.IX.2012, Yu. Sundukov (2 우, in ZMUM); Sakhalin I., Novo-Aleksandrovsk (44.0492N 142.7299E), 18.VII.1961, Krivolutskaya $\left(1 \sigma^{7}\right.$, in IBSS); Sakhalin I., Pereput'e (46.3075N 141.8922E), 22.VII. 1953, N. Filippov (1 $\mathrm{O}^{7}$ in ZMUM); Kunashir I., Tretyakovo (43.9913N 145.6555E), 10.VII.2085, S. Churkin (1 , in ZMUM); Kunashir I., Mendeleev Volkano env. (43.9610N 145.7290E), 26.VII.1985, S. Churkin (1 $\circ$, in ZMUM); Kuril Islands, Kunashir I., Ivanovskyi Cape $(43.828 \mathrm{~N} 145.400 \mathrm{E}), 1-$ 3.IX.2013, Yu. Sundukov ( $1 \mathrm{O}^{\prime}$, in ZMUM).

DISTRIBUTION. Russia: Amur Oblast, Jewish Autonomus Oblast, Kamchatka Kray, Khabarovsk Kray, Primorskiy Kray, Sakhalin Oblast (Kuril Is., Sakhalin I.); Zabaikalskiy Kray.

\section{Cordilura remota Ozerov, 1997}

The species was described from Amur Oblast and Primorskiy Kray [Ozerov, 1997: 1425], holotype in ZMUM [Ozerov, 2005]. 
DISTRIBUTION. Russia: Amur Oblast and Primorskiy Kray.

\section{Cordilura rufipes (Meigen, 1826)}

The species was registered for the Far East by Gorodkov [1986: 15, as Cordilura pubera Linnaeus, 1758] without specifying the place of collecting.

DISTRIBUTION. Russia: Far East [Gorodkov 1986: 15, as Cordilura pubera Linnaeus, 1758]; european part of Russia, Siberia. - widespread in Europe, Asia (Mongolia, China [e.g. Sun, 1996]).

Cordilura sagittifera Gorodkov, 1974

MATERIAL EXAMINED. Amur Oblast: Zeyskiy Reserve, "52 km" Cordon (54.0873N 126.8713E), 7.VIII.1981, A. Ozerov $\left(1 \mathrm{O}^{\mathrm{T}}, 1\right.$, , in ZMUM); Primorskiy Kray: Khanka Lake (45.06N 131.99E), 4-6.VII.2014, N. Vikhrev (1 O', in ZMUM).

DISTRIBUTION. Russia: Amur Oblast, Primorskiy Kray (first record for Russian Far East); Siberia. - Mongolia.

\section{Cordilura shatalkini Ozerov, 1997}

This species was described from Ryazanovka (42.7972N 131.2444E), Primorskiy Kray [Ozerov, 1997: 1425], holotype in ZMUM [Ozerov, 2005].

MATERIAL EXAMINED. Primorskiy Kray: Kedrovaya Pad' Reserve (43.1047N 131.5122E), 8.VII.1962, L. Zimina (1 $O$, in ZMUM); Kamenushka (43.6342N 132.2220E), 4.VI.1989, A Shatalkin $(1$, in ZMUM).

DISTRIBUTION. Russia: Primorskiy Kray.

Cordilura sidorenkoi Ozerov et Krivosheina, 2012

The species was described from Lazovskiy Reserve (43.0057N 134.1238E), Primorskiy Kray from a single specimen [Ozerov \& Krivosheina, 2012b: 2]. Holotype is kept in ZMUM.

DISTRIBUTION. Russia: Primorskiy Kray.

Cordilura sifneri Ozerov, 2007

Described from Primorskiy Kray (43.6342N 132.2220E) [Ozerov, 2007a: 126]. Holotype is kept in ZMUM.

MATERIAL EXAMINED. Primorskiy Kray: Lazovskiy Reserve, "Amerika" Cordon (43.2830N 134.0440E), 13-18.VII.1986, A.L. Ozerov (8 우, in ZMUM); Andreevka (ca. 42.64N 131.13E), 25-30.VI.2014, N. Vikhrev (1 9 , in ZMUM); Kamenushka (43.62N 132.23E), 22-24.VI.2014, N. Vikhrev (1 +, in ZMUM).

DISTRIBUTION. Russia: Primorskiy Kray. - Korea [Ozerov, 2009b]

\section{Cordilura tartariana Ozerov, 2007}

The species was described from town Zeya (53.7485N 127.2614E), Amur Oblast [Ozerov, 2007a: 126]. Holotype is kept in ZMUM.

MATERIAL EXAMINED. Khabarovsk Kray: Gobilli River (49.22N 138.25E), 8.VI.2014, N. Vikhrev (1 9 , in ZMUM); Primorskiy Kray: Andreevka (ca. 42.64N 131.13E), 25-30.VI.2014, N. Vikhrev (4 +9 , in ZMUM).
DISTRIBUTION. Russia: Amur Oblast, Khabarovsk Kray, Primorskiy Kray.

\section{Cordilura ustulata (Zetterstedt, 1838)}

MATERIAL EXAMINED. Amur Oblast: Nukzha River (56.5741N 121.6527E), 18.VI.1976, Soboleva (1 $\sigma^{\top}, 3$ 우, in IBSS); Primorskiy Kray: Lazovskiy Reserve, Korpad' Cordon (43.2529N 134.1265E), 19-20.V.2007, V. Sidorenko (1 9 , in ZMUM); Sakhalin Oblast: Kuril Islands, Shikotan I. Tserkovnaya Bay $(43.75 \mathrm{~N}$ 146.70E), 2-8.VI.2012, Yu. Sundukov (1 $\sigma^{7}$, in ZMUM)

DISTRIBUTION. Russia: Amur Oblast, Primorskiy Kray, Sakhalin Oblast (Kuril Is.) (first record for Russian Far East); european part of Russia, Siberia. - Europe, Asia (Mongolia), North America.

\section{Cordilura zaitzevi Gorodkov, 1974}

MATERIAL EXAMINED. Amur Oblast: Blagoveshchensk (50.2805N 127.5350E), 17.VIII.1982, A. Leley (1 + , in ZISP); town Zeya (53.7485N 127.2614E), 18 and 20.VII.1982, A. Ozerov, O. Gorbunov ( $2 \mathrm{O}^{\top} \mathrm{O}^{\top}, 1$, , in ZMUM); Primorskiy Kray: Bol'shaya Ussurka River, $20 \mathrm{~km}$ NW of Mel'nichnoe (45.5485N 135.3476E), 2.VIII.1986, A. Leley (1 $\sigma^{7}$, in IBSS); Kamenushka (43.6342N 132.2220E), 9 and 11.IX.1983, A.L. Ozerov (3 $\mathrm{O}^{7} \mathrm{O}^{7}$, in ZMUM).

DISTRIBUTION. Russia: Amur Oblast, Primorskiy Kray (first record for Russian Far East); Siberia. - Asia (Kazakhstan, Mongolia).

Ernoneura argus (Zetterstedt, 1838)

The species was registered for the Far East by Gorodkov [1986: 28] without specifying the place of collecting.

MATERIAL EXAMINED. Chukotka: Meynypil'gyno env. $(62.567 \mathrm{~N}$ 177.033E, 62.5385N 177.0519E), 14-21.VI.2010, 2327.VI., 10-13.VII.2011, 26-29.VI. and 3-13.VII.2012, 9.VII.2013, P.S. Tomkovich (17 $0^{7} \sigma^{7}, 13$ 우, in ZMUM).

DISTRIBUTION. Russia: Chukotka; european part of Russia, Siberia. - Europe, North America.

Gimnomera cuneiventris (Zetterstedt, 1846)

MATERIAL EXAMINED. Magadan Oblast: Sokol env. (59.92N 150.71E), 11-19.VII.2014, N. Vikhrev (4 O $^{\top} \mathrm{O}^{7}, 7$ 우, in ZMUM);

DISTRIBUTION. Russia: Magadan Oblast (first record for Russian Far East); north of european part of Russia [Gorodkov, 1986]. - Europe (Scandinavia, Slovakia [Šifner, 2008]).

\section{Gimnomera hirta (Hendel, 1930)}

MATERIAL EXAMINED. Amur Oblast: town Zeya (53.7485N 127.2614E), 19.VI.1978, A. Shatalkin (1 $0^{7}$, in ZMUM); Zeyskiy Reserve, "52 km" Cordon (54.0873N 126.8713E), 24.VII.1981, 6.VII.1982, A.L. Ozerov (2 O $^{7} \mathrm{O}^{7}, 5$ OP , in ZMUM).

DISTRIBUTION. Russia: Amur Oblast (first record for Russian Far East); european part of Russia, Siberia. - Europe (Scandinavia).

\section{Gimnomera lasiostoma (Becker, 1894)}

MATERIAL EXAMINED. Magadan Oblast: Sokol env. (59.92N 150.71E), 11-19.VII.2014, N. Vikhrev (1 $\sigma^{\top}, 10$ 90, in 
ZMUM); Donyshko River (60.41N 151.52E), 17.VII.2014, N. Vikhrev (1 , in ZMUM);

DISTRIBUTION. Russia: Magadan Oblast (first record for Russian Far East and Russia). - Europe (Austria, Bosnia-Hercegovina, Switzerland [Šifner, 2008]).

\section{Gimnomera sibirica (Engelmark, 1999)}

The species was described from Wrangel Island (70.9666N 179.5666E), Chukotka, and Yakutia [Engelmark, 1999: 165]; holotype in MZLU.

DISTRIBUTION. Russia: Chukotka; Yakutia.

Gimnomera tukuringra Ozerov, 1999

Described from town Zeya (53.7485N 127.2614E), Amur Oblast from a single specimen [Ozerov, 1999b: 636]. Holotype is kept in ZMUM [Ozerov, 2005].

DISTRIBUTION. Russia: Amur Oblast.

Gonatherus planiceps (Fallén, 1826)

fumipennis Hendel, 1930: 7 (Gonatherus). Synonymized by Ozerov [2007c: 6].

Hendel [1930: 7, as G. fumipennis] mentioned this species from Kamchatka Kray, Kluchi firstly for Russian Far East. Holotype of G. fumipennis is kept in NHRS [Ozerov, 2007c].

DISTRIBUTION. Russia: Kamchatka Kray; european part of Russia, Altay. - Europe, North America.

Hexamitocera loxocerata (Fallén, 1826)

MATERIAL EXAMINED. Magadan Oblast: Sokol env. (59.92N 150.71E), 11-19.VII.2014, N. Vikhrev (in ZMUM); Sakhalin Oblast: Kuril Islands, Paramushir I., Rifovaya Bay (50.4953N 156.1118E), 30.VII.1999, A. Leley, S. Storozhenko (1 +, in ZMUM).

DISTRIBUTION. Russia: Magadan Oblast, Sakhalin Oblast (first record for Russian Far East); european part of Russia [Hackman, 1956]. - Europe.

\section{Langechristia amica Ozerov, 1999}

The species was described from Primorskiy Kray (30 km SE of Chuguevka) [Ozerov, 1999a: 511]. Holotype of this species is kept in ZMB [Ozerov, 2014].

DISTRIBUTION. Russia: Primorskiy Kray.

\section{Langechristia speciosa Ozerov, 1999}

This species was described from Primorskiy Kray (30 km SE of Chuguevka) [Ozerov, 1999a: 511]; holotype is kept in ZMB [Ozerov, 2014].

DISTRIBUTION. Russia: Primorskiy Kray.

\section{Langechristia ziegleri Ozerov, 1999}

Described from Boitsovo, Khabarovsk Kray [Ozerov, 1999a: 510]. Holotype of this species is kept in ZMB [Ozerov, 2014].
DISTRIBUTION. Russia: Khabarovsk Kray.

Megaphthalma pallida (Fallén, 1819)

The species was firstly registered for the Far East by Ozerov [2009b: 379] from Lazovsky Reserve, Primorskiy Kray.

MATERIAL EXAMINED. Magadan Oblast: Sokol env. (59.92N 150.71E), 11-19.VII.2014, N. Vikhrev (1 + , in ZMUM); Primorskiy Kray: Bikin River, $22 \mathrm{~km}$ above the mouth of Svetlovodnaya River (46.6166N 137.0543E), 14.VIII.1980, V. Zlobin $\left(1 O^{2}\right.$, in ZISP).

DISTRIBUTION. Russia: Magadan Oblast, Primorskiy Kray; european part of Russia, Siberia. — Europe, North America.

Megaphthalmoides unilineatus (Zetterstedt, 1838)

MATERIAL EXAMINED. Amur Oblast: basin of Nora River, Sorokoverstnaya Channel (52.5282N 129.9659E), 28.VII.2008, E.M. Veselova, A.B. Ryvkin (1 $\sigma^{7}, 1$ ㅇ, in ZMUM); Chukotka: lower reaches of the Anadyr River (64.83N 175.96E), 5 m., 29.VII. and 5.VIII.2013, O. Khruleva (3 $0^{7} \sigma^{7}, 10$ 우 , in ZMUM);

DISTRIBUTION. Russia: Chukotka and Primorskiy Kray (first record for Russian Far East); european part of Russia, Siberia. - Europe (central part, Scandinavia), North America.

Microprosopa haemorrhoidalis (Meigen, 1826)

The species was registered for the Far East by Gorodkov [1986: 25] without specifying the place of collecting.

MATERIAL EXAMINED. Amur Oblast: town Zeya (53.7485N 127.2614E), 16.VII.1982, A.L. Ozerov (3 $\sigma^{7} \sigma^{7}$, in ZMUM); Zeyskiy Reserve, "52 km" Cordon (54.0873N 126.8713E), 13-24.VIII.1981, A. Shatalkin, A.L. Ozerov (41 $\sigma^{7} \sigma^{7}, 16$ 오, in ZMUM); Chukotka: lower reaches of the Anadyr River (64.83N 175.96E), 5 m., 18.VII. and 4.VIII.2013, A. Barkalov (5 $0^{71} 0^{73}$, in ZMUM and ISEA); Kamchatka Kray: Zhupanovo (54.0822N 159.9811E), 2.VII.1988, L. Lobkova, (1 $\sigma^{7}$, in ZMUM); Kozlov Cape (54.8344N 162.1506E), 4.VII.1988, L. Lobkova (3 OP, in ZMUM); Uzon (54.5033N 159.9900E), 16-17.VII.2009, L. Lobkova (1 $\sigma^{7}$, in ZMUM); Magadan Oblast: Susuman $(62.7772 \mathrm{~N}$ 148.1415E), 10.VII.1963, Zhelokhovtsev (1 $0^{7}$, in ZMUM); Ust'Omchug (61.1356N 149.6349E), 3.VII.1978, V. Zherikhin \& N. Sinichenkova (3 웅, in ZMUM); Sokol env. (59.92N 150.71E), 11-19.VII.2014, N. Vikhrev (11 $0^{7} \sigma^{7}, 1$ o in ZMUM); Yablonevyy Pass (60.59N 151.53E), $900 \mathrm{~m}, 16-18$. VII.2014, N. Vikhrev $\left(1 O^{7}\right.$, in ZMUM); Primorskiy Kray: Ust'-Chaun Pass (66.7759N 170.5025E), $6800 \mathrm{~m}, 8$. VIII.1970, Petrova (1 $\sigma^{7}$, in IBSS).

DISTRIBUTION. Russia: Amur Oblast, Chukotka, Kamchatka Kray, Magadan Oblast, and Primorskiy Kray; european part of Russia, Siberia. - Europe, North America.

\section{Microprosopa heteromyzina (Zetterstedt, 1838)}

MATERIAL EXAMINED. Chukotka: lower reaches of the Anadyr River (64.83N 175.96E), 27-30.VII.2013, A. Barkalov (1 + , in ZMUM); Magadan Oblast: Sokol env. (59.92N 150.71E), 11-19.VII.2014, N. Vikhrev (1 $\bigcirc^{7}$, in ZMUM).

DISTRIBUTION. Russia: Chukotka, Magadan Oblast (first record for Russian Far East); european part of Russia. - Europe (Slovakia, Sweden, Czech Republic), North America. 
Microprosopa pallidicauda (Zetterstedt, 1838)

MATERIAL EXAMINED. Kamchatka Kray: Bering I., Stolovaya Montain (55.2526N 166.0430E), 20.VII.1988, A.N. Pegova (1 O', in ZMUM); Uzon (54.4877N 159.9772E), 2-11.VII.1987, L. Lobkova (14 O $0^{\top} \mathrm{O}^{7}, 4$ 우, in ZMUM); Ust'-Kamchatsk (55.2410N 162.5361E), 11.VII.1930, V.I. Sychevskaya (1 $\sigma^{7}$, in ZMUM); Bering I., Nikol'skoe (55.1966N 166.0116E), 12.VIII.1977, Yu.D. Bodrova ( $1 \sigma^{7}$, in IBSS); Khabarovsk Kray: Chistovodnaya River (49.10N 139.83E), $460 \mathrm{~m}, 10 . \mathrm{VI} .2014$, N. Vikhrev (1 o , 1 \%, in ZMUM); Magadan Oblast: (59.6666N 150.6666E), 8.VII.1978, V. Zherikhin (3 $\mathrm{O}^{7} \mathrm{O}^{7}, 1$ \% , in ZMUM); Sokol env. (59.92N 150.71E), 11-19.VII.2014, N. Vikhrev (4 $\bigcirc^{7} \sigma^{7}, 5$ 우, in ZMUM).

DISTRIBUTION. Russia: Chukotka, Kamchatka Kray, Khabarovsk Kray (first record for Russian Far East); european part of Russia, Siberia. - Europe, North America.

Microprosopa paveli Ozerov et Krivosheina, 2013

The species was described from Chukotka (Meynipyl'gino (62.5385N 177.0519E) [Ozerov \& Krivosheina 2013b: 4]. Holotype is kept in ZMUM.

DISTRIBUTION. Russia: Chukotka Kray.

Nanna amurensis Ozerov, 2010

This species was described from town Zeya (53.7485N 127.2614E), Amur Oblast [Ozerov, 2010d: $160,164]$, holotype is kept in ZMUM.

MATERIAL EXAMINED. Khabarovsk Kray: Vanino (49.11N 140.31E), 9.VI.2014, N. Vikhrev (4 $\sigma^{7} \sigma^{7}$, in ZMUM); Kirpichnyy Stream (49.261N 140.33E), 11.VI.2014, N. Vikhrev (1 O', in ZMUM); Khicha River (49.05N 139.43E), 690 m, 10.VI.2014, N. Vikhrev (2 $\sigma^{7} \sigma^{7}$, in ZMUM); Khabarovsk (48.6N 135.1E), 2-6. and 13.VI.2014, N. Vikhrev (1 9 , in ZMUM); Magadan Oblast: Sokol env. (59.92N 150.71E), 11-19.VII.2014, N. Vikhrev (1 O', in ZMUM); Primorskiy Kray: Khasan env. (42.4245N 130.6511E), 25.V.1979, A. Zinov'ev (1 O', in ZISP);

DISTRIBUTION. Russia: Amur Oblast, Khabarovsk Kray, Magadan Oblast, Primorskiy Kray.

\section{Nanna flavipes (Fallén, 1819)}

MATERIAL EXAMINED. Amur Oblast: Zeyskiy Reserve, “52 km" Cordon (54.0873N 126.8713E), 29.VI.1982, M. Krivosheina (1 $\sigma^{7}$, in ZMUM); Nukzha River (56.5741N 121.6527E), 27.VI.1976, Soboleva ( 1 , in IBSS); Khabarovsk Kray: Vanino (49.11N 140.31E), 9.VI.2014, N. Vikhrev (2 $\sigma^{\top} \sigma^{\top}, 2$ + 9 , in ZMUM); Kirpichnyy Stream (49.261N 140.33E), 11.VI.2014, N. Vikhrev (9 $\sigma^{7} \sigma^{7}, 6$ O+口, in ZMUM); Khicha River (49.05N 139.43E), $690 \mathrm{~m}$, 10.VI.2014, N. Vikhrev (1 $\sigma^{7}, 2$ 우, in ZMUM); Khabarovsk (48.6N 135.1E), 2-6. and 13.VI.2014, N. Vikhrev (1 9, in ZMUM); Magadan Oblast: Sokol env. (59.92N 150.71E), 11-19.VII.2014, N. Vikhrev ( 1 , in ZMUM); Primorskiy Kray: Lazovskiy Reserve, Proselochnyy Cordon (43.0057N 134.1238E), 22-23.V.2007, V. Sidorenko (2 $\sigma^{7} \sigma^{7}$, in ZMUM).

DISTRIBUTION. Russia: Amur Oblast, Khabarovsk Kray, Magadan Oblast, Primorskiy Kray (first record for Russian Far East); european part of Russia, Siberia. - Europe (widespread), Asia (Mongolia).

\section{Nanna katmaiensis (Malloch, 1920)}

kamtschatkense Hendel, 1930: 9 (Amaurosoma). Synonymized by Ozerov [2007c: 7]. Holotype of this species is kept in NHRS [Ozerov, 2007c]. variojemoratum Hendel, 1930: 10 (Amaurosoma, as variety of kamtschatkense). Synonymized by Ozerov [2007c: 8]; holotype is kept in NHRS [Ozerov, 2007c].

The species was firstly registered for the Far East by Hendel [1930: 9, as A. kamtschatkense] from Kamchatka Kray.

MATERIAL EXAMINED. Khabarovsk Kray: Vanino (49.11N 140.31E), 9.VI.2014, N. Vikhrev (4 $\sigma^{\top} \sigma^{\top}, 4$ oq , in ZMUM); Kirpichnyy Stream (49.261N 140.33E), 11.VI.2014, N. Vikhrev ( $\sigma^{7} \sigma^{7}, 1$ q, in ZMUM); Magadan Oblast: Ust'-Omchug (61.1356N 149.6349E), 3.VII.1978, V. Zherikhin \& N. Sinichenkova ( 1 , in ZMUM); Sokol env. (59.92N 150.71E), 1119.VII.2014, N. Vikhrev ( 1 , in ZMUM); Nagaev Bay $(59.53 \mathrm{~N}$ 150.76E), 20-22.VII.2014, N. Vikhrev (1 $\sigma^{7}, 1$, in ZMUM); Sakhalin Oblast: Kuril Islands, Shikotan I. Tserkovnaya Bay (43.75N 146.70E), 23-31.V. and 2-14.VI.2012, Yu. Sundukov ( $28 \bigcirc^{7} \sigma^{\top}, 3$ 우, in ZMUM).

DISTRIBUTION. Russia: Kamchatka Kray, Khabarovsk Kray, Magadan Oblast, and Sakhalin Oblast (Kuril Is.). — North America.

\section{Nanna leucostoma (Zetterstedt, 1846)}

MATERIAL EXAMINED. Amur Oblast: Zeyskiy Reserve, “52 km" Cordon (54.0873N 126.8713E), 29.VI.1982, M. Krivosheina ( $1 \sigma^{7}$, in ZMUM); Khabarovsk Kray: Kirpichnyy Stream (49.261N 140.33E), 11.VI.2014, N. Vikhrev (1 $\sigma^{7}, 1$, in ZMUM); Taunga River (49.289N 138.594E), 600 m, 12.VI.2014, N. Vikhrev ( 1 , in ZMUM); Khicha River (49.05N 139.43E), 690 m, 10.VI.2014, N. Vikhrev (1 9 , in ZMUM); Magadan Oblast: Sokol env. (59.92N 150.71E), 11-19.VII.2014, N. Vikhrev (1 9 , in ZMUM).

DiSTRIBUTION. Russia: Amur Oblast, Khabarovsk Kray, Magadan Oblast (first record for Russian Far East).

Nanna loewi (Becker, 1894)

carbonarium Hendel, 1930: 11 (Amaurosoma). Synonymized by Ozerov [2007c: 6]. Holotype of this species is kept in NHRS [Ozerov, 2007c].

The species was firstly registered for the Far East by Hendel [1930: 9, as A. carbonarium] from Kamchatka Kray.

DISTRIBUTION. Russia: Kamchatka Kray. — Europe (Poland), Asia (Mongolia).

\section{Nanna obscuripes (Becker, 1915)}

indotatum Engelmark, 1999: 164 (Nanna). Synonymized by Ozerov \& Krivosheina [2013a: 144]. Holotype of this species is kept in MZLU [Engelmark, 1999].

The species was firstly registered for the Far East by Engelmark [1999: 164, as Nanna indotatum] from Ayon Island (69.7833N 168.5666E), Chukotka.

DISTRIBUTION. Russia: Chukotka; Tyumen' Oblast.

Nanna rossolimoae Ozerov, 2010

The species was described from town Zeya (53.7485N 127.2614E), Amur Oblast [Ozerov, 2010d: $161,165]$; holotype is kept in ZMUM.

DISTRIBUTION. Russia: Amur Oblast. 
Neochirosia veratri (Hendel, 1925)

MATERIAL EXAMINED. Chukotka: lower reaches of the Anadyr River (64.83N 175.96E), 5 m., 25.VII.2013, O. Khruleva (1 , in ZMUM), 27-30.VII.2013, A. Barkalov (2 $\mathrm{O}^{7} \mathrm{O}^{x}, 1$ 우 , in ZMUM and ISEA); Khabarovsk Kray: Manoma River (49.44N 137.41E), 8.VI.2014, N. Vikhrev (1 $\sigma^{7}$, in ZMUM); Taunga River $(49.289 \mathrm{~N}$ 138.594E), $600 \mathrm{~m}, 12 \mathrm{VI} .2014, \mathrm{~N}$. Vikhrev (1 $\circ$, in ZMUM); Magadan Oblast: Sokol env. (59.92N 150.71E), 1119.VII.2014, N. Vikhrev (11 $0^{7} O^{7}, 5$ 우, in ZMUM); Sakhalin Oblast: Kuril Islands, Shikotan I. Tserkovnaya Bay (43.75N 146.70E), 23-31.V. and 10-14.VI.2012, Yu. Sundukov (1 $\mathrm{O}^{\top}, 3$ +क , in ZMUM); Kuril Islands, Kunashir I., Ivanovskyi Cape (43.828N 145.400E), 23-29.V.2013, Yu. Sundukov (2 Oे $^{7}$, in ZMUM).

DISTRIBUTION. Russia: Chukotka, Khabarovsk Kray, Magadan Oblast, Sakhalin Oblast (Kuril Is.) (first record for Russian Far East); european part of Russia, Siberia. - Europe.

\section{Norellisoma insulare (Ozerov, 1993)}

This species was described from Kunashir I., Kuril Islands, Sakhalin Oblast [Ozerov, 1993: 71]. Holotype is kept in ZMUM [Ozerov, 2005].

MATERIAL EXAMINED. Sakhalin Oblast: Kuril Islands, Shikotan I., Tserkovnaya Bay (43.75N 146.70E), 23-31.V.2012, Yu. Sundukov ( $70^{7} O^{7}, 6$ ㅇ, in ZMUM); Kunashir I., Alekhinsky Cape (43.9183N 145.5261E), 19-21.IX.2009, I. Melnik (1 O', 1 ㅇ, in ZMUM); Kunashir I., Tretyakovo (43.9913N 145.6555E), 1322.IX.2009, I. Melnik (1 $\circ$, in ZMUM); Kunashir I., Mendeleev Volkano env. (43.9610N 145.7290E), 4.VII.1985, S. Churkin (2 우, in ZMUM); Sakhalin I., Tymovo env. (51.1281N 142.6751E), 1.VI.1979, A. Veselkin ( $1 \mathrm{O}^{7}$ in ZMUM); Kuril Islands, Kunashir I., Filatovka River (44.186N 146.025E), 25-27.VI.2013, Yu. Sundukov (3 $\sigma^{7} \sigma^{7}$, in ZMUM); Kuril Islands, Kunashir I., Ivanovskyi Cape (43.828N 145.400E), 23-29.V.2013, Yu. Sundukov (3 O $^{7} \mathrm{O}^{7}$, 1 , in ZMUM); Kuril Islands, Kunashir I., the mouth of the Bystryi Stream (43.787N 145.422E), 27.V.2013, Yu. Sundukov (1 $\sigma^{7}, 1$ \% , in ZMUM).

DISTRIBUTION. Russia: Sakhalin Oblast (Kuril Is., Sakhalin I.). — Asia (Japan [Hironaga \& Suwa, 2005]).

\section{Norellisoma orientale (Ozerov, 1993)}

Described from Amur Oblast and Primorskiy Kray [Ozerov, 1993: 70]. Holotype is kept in ZMUM [Ozerov, 2005].

MATERIAL EXAMINED. Amur Oblast: basin Nora River, Sorokoverstnaya Channel (52.5282N 129.9659E), 1.VIII.2006, E.M Veselova, A.B. Ryvkin (1 9 , in ZMUM); Selemzha River between mouth of the Nora River and Ust'-Norsk Sopka, 8.VIII.2006, E.M Veselova, A.B.Ryvkin ( 1 + , in ZMUM); Primorskiy Kray: Bikin River, $22 \mathrm{~km}$ abobe the mouth of Svetlovodnaya River $(46.6166 \mathrm{~N}$ 137.0543E), 14.VIII.1980, V. Zlobin (1 $O^{7}$, in ZISP).

DISTRIBUTION. Russia: Amur Oblast and Primorskiy Kray. - Asia (Japan [Hironaga \& Suwa, 2005]).

\section{Norellisoma spinimanum (Fallén, 1819)}

septentrionale Hendel, 1930: 2 (Norelliosoma). Synonymized by Ozerov [2007c: 7]. Holotype of this species is kept in NHRS [Ozerov, 2007c].

The species was firstly registered for the Far East by Hendel [1930: 3, as Norelliosoma septentrionale] from Kamchatka Kray.
MATERIAL EXAMINED. Amur Oblast: Zeyskiy Reserve, "52 km" Cordon (54.0873N 126.8713E), 27.VI.1982, A.L. Ozerov $(1$ 9 , in ZMUM); Khabarovsk Kray: Khicha River $(49.05 \mathrm{~N}$ 139.43E), 690 m, 10.VI.2014, N. Vikhrev (1 ㅇ, in ZMUM); Vanino $(49.11 \mathrm{~N} 140.31 \mathrm{E}), 9 . V I .2014, \mathrm{~N}$. Vikhrev (1 $\mathrm{O}^{7}, 2$ oㅇ, in ZMUM); Magadan Oblast: (55.5682N 150.8091E), 18.VI.1963, Zhelokhovtsev (1 $\mathrm{O}^{7}$, in ZMUM) Sokol env. (59.92N 150.71E), 11-19.VII.2014, N. Vikhrev (1 + , in ZMUM).

DISTRIBUTION. Russia: Amur Oblast, Kamchatka Kray, Khabarovsk Kray, Magadan Oblast; european part of Russia, Siberia. - Europe (widespread), Asia (China [Sun, 1996]), North America.

\section{Okeniella dasyprocta (Loew, 1864)}

The data on distribution of this species for the Far East was given by Gorodkov [1984, 1986].

MATERIAL EXAMINED. Chukotka: Apapel'gin River (68.8N 170.65E), 5.VII.2011, O.A. Khruleva (8 $0^{7} \sigma^{7}, 7$ of 9 , in ZMUM); Meynypil'gyno env. (62.5385N 177.0519E, 62.567N 177.033E), 14-21.VI.2010, 23-27.VI.2011, 26-29.VI. and 3-13.VII.2012, 9, 19 and 20.VII.2013, P.S. Tomkovich (14 $\sigma^{7} \sigma^{7}, 7$ q9, in ZMUM); lower reaches of the Anadyr River (64.83N 175.96E), 5 m., 1828.VII.2013, A. Barkalov (4 $\sigma^{7} \sigma^{7}$, in ISEA); Kamchatka Kray: Uzon $(54.4877 \mathrm{~N} 159.9772 \mathrm{E}, 54.5033 \mathrm{~N} 159.9900 \mathrm{E}), 9$ and 11.VII.1987, L. Lobkova (4 $\sigma^{7} \sigma^{7}$, in ZMUM); Magadan Oblast: Sokol env. (59.92N 150.71E), 11-19.VII.2014, N. Vikhrev (4 O Oొ $^{7}$, 6 우, in ZMUM).

DISTRIBUTION. Russia: Chukotka, Kamchatka Kray, Magadan Oblast; european part of Russia, Siberia. - Europe (Scandinavia), North America.

\section{Orthacheta cornuta (Loew, 1863)}

fuscipennis Hendel, 1930: 8 (Orthochaeta). Synonymized by Ozerov [2007c: 6]. Holotype of this species is kept in NHRS [Ozerov, 2007c].

The species was firstly registered for the Far East by Hendel [1930: 3, as Orthochaeta fuscipennis] from Kamchatka Kray.

MATERIAL EXAMINED. Kamchatka Kray: Vestnik Bay (51.4823N 157.5301E), 27.VII.1999, A. Leley, S. Storozhenko (1 $\sigma^{7}$, in ZMUM); Primorskiy Kray: Lazovskiy Reserve, Korpad' Cordon (43.2529N 134.1265E), 19-20.V.2007, V. Sidorenko (1 , in ZMUM).

DISTRIBUTION. Russia: Kamchatka Kray, Primorskiy Kray. — North America.

\section{Orthacheta pilosa (Zetterstedt, 1838)}

MATERIAL EXAMINED. Magadan Oblast: Sokol env. (59.92N 150.71E), 11-19.VII.2014, N. Vikhrev (1 +, in ZMUM); Primorskiy Kray: Gribnoe, $10 \mathrm{~km}$ SE of Chernigovka (44.2581N 132.6813E), 20.V.1979, A. Zinov'ev (2 $0^{7} \sigma^{7}$, in ZISP).

DISTRIBUTION. Russia: Magadan Oblast, Primorskiy Kray (first record for Russian Far East); european part of Russia, Siberia. — Europe, Asia (Mongolia).

\section{Parallelomma sellatum (Hackman, 1956)}

MATERIAL EXAMINED. Amur Oblast: town Zeya (53.7485N $127.2614 \mathrm{E})$ and Zeyskiy Reserve $(53.9899 \mathrm{~N} 127.0735 \mathrm{E}, 54.0873 \mathrm{~N}$ 126.8713E), 4 and 28.VII.1978 A. Shatalkin (1 $\sigma^{7}, 2$ 우, in ZMUM); same locality, 24.VII., 4.VIII., 12.VIII. and 22.VIII.1979, A. Shatalkin (4 90 , in ZMUM), 10.VII.-1.VIII. and 2.IX.1981, A. Ozerov, A. 
Shatalkin (7 $0^{7} \sigma^{7}, 8$ 우 , in ZMUM), 3.VII--12.VIII.1982, M. Krivosheina, A. Ozerov, A. Shatalkin ( $9 \mathrm{O}^{7} \mathrm{O}^{7}, 17$ 우 , in ZMUM).

DISTRIBUTION. Russia: Amur Oblast (first record for Russian Far East); european part of Russia, Siberia. — Europe (Finland).

\section{Parallelomma vittatum (Meigen, 1826)}

MATERIAL EXAMINED. Amur Oblast: town Zeya $(53.7485 \mathrm{~N} 127.2614 \mathrm{E})$ and Zeyskiy Reserve $(53.9899 \mathrm{~N} 127.0735 \mathrm{E}$, $54.0873 \mathrm{~N} 126.8713 \mathrm{E})$, 5.VII.1978 A. Shatalkin (1 $\mathrm{O}^{7}, 2$ 우, in ZMUM), 23.VI. and 27.VII.1979, A. Shatalkin (2 90 , in ZMUM), 9-24.VII.1981, A. Ozerov, A. Shatalkin (3 $\sigma^{7} \sigma^{7}, 9$ 오, in ZMUM), 27.VI., 10-27.VII. and 3.VIII.1982, M. Krivosheina, A. Ozerov, A. Shatalkin (3 $0^{7} O^{7}, 2$ ㅇ, in ZMUM); Jewish Autonomus Oblast: Malyy Khingan Range, Dichun River (48.5459N 130.7603E), 10.VII.1979 and 25.VII.1984, A. Shatalkin (2 99 , in ZMUM); Primorskiy Kray: Vladivostok env., Sedanka (43.2179N 131.9519E), 21.VI.1937, N. Filippov (1 $\sigma^{7}$, in ZMUM); Kamenushka (43.6342N 132.2220E), 13.VIII.1987, A. Shatalkin (1 $\sigma^{7}$, in ZMUM); Ryazanovka (42.7972N 131.2444E), 8.VI.1989, A Shatalkin $\left(1 \mathrm{O}^{7}\right.$, in ZMUM); Kedrovaya Pad' Reserve $(43.1047 \mathrm{~N}$ 131.5122E), 5.IX.1984, S. Churkin (1 $\mathrm{O}^{7}$, in ZMUM); $6 \mathrm{~km} \mathrm{~S}$ of Shebunino (46.373197N 141.871312E), 6.VIII.2004, A. Leley, S. Storozhenko (1 $\sigma^{7}$, in ZMUM); Sakhalin Oblast: Kuril Islands, Iturup I., Slavnaya Bay (45.5040N 148.6383E), 11.VIII.1996, A. Leley, S. Storozhenko (1 9 , in ZMUM); Kuril Islands, Kunashir I. Tretyakovo (43.9913N 145.6555E), 13-22.IX.2009, I. Melnik (1 , in ZMUM); Kuril Islands, Kunashir I., Grozovoe env. (43.8396N 145.4110E), 8-15. VIII.2008, I. Melnik (1 $\sigma^{7}$, in ZMUM); Kuril Islands, Shikotan I. Tserkovnaya Bay $(43.75 \mathrm{~N}$ 146.70E), 18 30.VIII.2012, Yu. Sundukov (1 $\sigma^{7}, 1$, in ZMUM); Kuril Islands, Kunashir I., Filatovka River (44.186N 146.025E), 25-27.VI.2013, Yu. Sundukov (1 $\sigma^{7}$, in ZMUM); Kuril Islands, Kunashir I., caldera of the Golovin Volcano (43.859N 145.505E), 7-9.VI.2013, Yu. Sundukov ( 1 + , in ZMUM).

DISTRIBUTION. Russia: Amur Oblast, Jewish Autonomus Oblast, Primorskiy Kray, Sakhalin Oblast (Kuril Is.) (first record for Russian Far East); european part of Russia, Siberia. - Europe (widespread), Asia (China [Sun, 1996], Japan), North America.

\section{Pleurochaetella simplicipes (Becker, 1900)}

The species was firstly registered for the Far East by Ozerov \& Krivosheina [2012a: 436] from Chukotka.

MATERIAL EXAMINED. Kamchatka Kray: Uzon, Tsentral'noe Lake (54.5064N 160.0326E), 24.VII.1977, Stenchenko (1 $\sigma^{7}$, in ZMUM); Chukotka: Meynypil'gyno env. (62.5385N 177.0519E), 19.VII.2013, P.S. Tomkovich (1 $\sigma^{7}$, in ZMUM).

DISTRIBUTION. Russia: Chukotka, Kamchatka Kray; north of european part of Russia, Siberia. Europe (Scandinavia), Asia (Mongolia [Gorodkov, 1986]), North America.

\section{Pogonota barbata (Zetterstedt, 1838)}

MATERIAL EXAMINED. Amur Oblast: town Zeya (53.7485N 127.2614E), 11 and 21.VI.1978, A. Shatalkin (1 $\sigma^{\top}, 1$ + , in ZMUM); Chukotka: lower reaches of the Anadyr River (64.83N 175.96E), 5 m., 28 and 31.VII.2013, A. Barkalov (2 90 , in ISEA); Kamchatka Kray: Uzon (54.5033N 159.9900E, $54.4877 \mathrm{~N}$ 159.9772E), Komariny creek floodplain, 20.VII.2009, L. Lobkova (2 $\sigma^{7} \sigma^{\top}$, in ZMUM); Sakhalin Oblast: Starodubskoe (47.4114N 142.8046E), 1.VIII.1972, I. Sukacheva (1 9 , in ZMUM).

DISTRIBUTION. Russia: Amur Oblast, Chukotka, Kamchatka Kray, Sakhalin Oblast (first record for
Russian Far East); european part of Russia, Siberia. — Europe, North America.

\section{Pogonota immunda (Zetterstedt, 1838)}

Registered for the Far East by Gorodkov [1986: 22] without specifying the place of collecting.

MATERIAL EXAMINED. Chukotka: Meynypil'gyno env. (62.5385N 177.0519E), 26-29.VI. and 3-13.VII.2012, 19.VII.2013, P.S. Tomkovich (17 $0^{7} \mathrm{O}^{7}, 8$ 우, in ZMUM).

DISTRIBUTION. Russia: Chukotka; european part of Russia, Siberia. - Europe (Scandinavia), North America.

\section{Pogonota sahlbergi (Becker, 1900)}

The species was registered for the Far East by Gorodkov [1986: 22] without specifying the place of collecting.

MATERIAL EXAMINED. Chukotka: Meynypil'gyno env. $(62.5385 \mathrm{~N} 177.0519 \mathrm{E}, 62.567 \mathrm{~N} 177.033 \mathrm{E}), 14-21 . \mathrm{VI} .2010,23-$ 27.VI..2011, 26-29.VI. and 3-13.VII.2012, 9 and 19.VII.2013, P.S. Tomkovich (26 $0^{7} O^{7}, 10$ 우, in ZMUM).

DISTRIBUTION. Russia: Chukotka; european part of Russia [e.g. Gorodkov, 1970], Siberia. - Europe (North Scandinavia), Asia (Mongolia [Šifner, 1975]), North America.

\section{Scathophaga apicalis (Curtis in Ross, 1835)}

The species was firstly registered for the Far East by Gorodkov [1986: 29] from Wrangel Island, Chukotka.

DISTRIBUTION. Russia: Chukotka; north of european part of Russia, arctic Siberia. - Europe (Sweden), North America.

\section{Scathophaga cordylurina (Holmgren, 1883)}

Registered for the Far East by Gorodkov [1986: 30] without specifying the place of collecting.

MATERIAL EXAMINED. Chukotka: Vrangel I., Somnitel'nye Montain (71.0N 179.5333E), 14.VII.-15.VIII.2006, O. Khruleva (1 $\mathrm{O}^{7}, 1$ \% , in ZMUM); Khabarovsk Kray: Gobilli River (49.22N 138.25E), 8.VI.2014, N. Vikhrev (1 $0^{7}$, in ZMUM).

DISTRIBUTION. Russia: Chukotka, Khabarovsk Kray; north of european part of Russia, north of Siberia.

\section{Scathophaga crinita (Coquillett, 1901)}

This species was described from Bering I., Commander Islands [Coquillett, 1901: 612]. Holotype of this species is kept in USNM.

MATERIAL EXAMINED. Chukotka: Goryachie klyuchi (65.5774N -171.4917W), 30-31.VII., 2.VIII.1960, Kononov (3 $\mathrm{O}^{\top} \mathrm{O}^{\top}$, in ZMUM); Ayon I. (69.8321N 168.6578E), 25.VI.1958, V. Lebe$\operatorname{dev}\left(1 \sigma^{7}\right.$, in ZMUM); Pevek env. (69.6N 170.25E), 23.VI.2011, O.A. Khruleva (2 $\sigma^{7} O^{7}$, in ZMUM); Chaplino $(64.4069 \mathrm{~N}$ 172.2409W), 7.VIII.1963, A. Tsvetaev (1 o7, 3 오, in ZMUM); Kamchatka Kray: Bering I., northwest rookery of seals (55.2851N 165.7558E), 17.VIII.1977, Yu.D. Bodrova (1 9 , in IBSS); Mednyy I., Preobrazhenskoe (54.7910N 167.5777E), 25.VII.1953, S. Mara$\operatorname{kov}\left(20^{7} \sigma^{7}, 1\right.$, , in ZMUM).

DISTRIBUTION. Russia: Chukotka, Kamchatka Kray. - North America. 


\section{Scathophaga dasythrix (Becker, 1894)}

The species was described from Kamchatka Kray (Mednyy I.) by Becker [1894: 173]. Lectotype was designated by Ozerov [2014: 36] and is kept in ZMB.

MATERIAL EXAMINED. Chukotka: Meynypil'gyno env. (62.5385N 177.0519E), 20.VII.2013, P.S. Tomkovich (1 ○’, 2 우, in ZMUM); Kamchatka Kray: Lopatka Cape $(50.8758 \mathrm{~N}$ 156.6660E), 9-10.IX.1987, L. Lobkova (1 O, in ZMUM); Bering I., Nikol'skoe (55.1966N 166.0116E), 12.VIII.1977, Yu.D. Bodrova $\left(1 \mathrm{O}^{7}\right.$, in IBSS); Mednyy I., Preobrazhenskoe (54.7910N 167.5777E), 30.VIII.1953, S. Marakov (1 O'7, in ZMUM); Sakhalin Oblast: Kuril Islands, Paramushir I., S.-Kuril'sk env. (50.6758N 156.1188E), 31.VII.1978, V. Barkalov (1 $\sigma^{7}$, in IBSS); Kuril Islands, Onekotan I., Subbotin Cape (49.4144N 154.6561E), 5.VIII.1996, A. Leley (1 9 , in ZMUM); Kuril Islands, Shumshu I. (50.7486N 156.3438E), 8.VIII.1997, A. Leley, S. Storozhenko (2 $0^{7} \sigma^{7}$, in ZMUM).

DISTRIBUTION. Russia: Chukotka, Kamchatka Kray, Sakhalin Oblast (Kuril Is.). — North America.

\section{Scathophaga exalata Ozerov, 1996}

This species was described from Kuril Islands, Sakhalin Oblast [Ozerov, 1996: 2]. Holotype is kept in ZMUM [Ozerov, 2005].

DISTRIBUTION. Russia: Sakhalin Oblast (Kuril Is.).

\section{Scathophaga furcata (Say, 1823)}

The data on distribution of this species for the Far East was given by Gorodkov [1978, 1986].

MATERIAL EXAMINED. Amur Oblast: Zeyskiy Reserve, “52 km" Cordon (54.0873N 126.8713E), 13.VIII.1981, A.L. Ozerov (3 $O^{7} O^{7}, 1$, in ZMUM); Chukotka: Pevek env. (69.70N $170.35 \mathrm{E}, 69.666 \mathrm{~N} 170.266 \mathrm{E}, 69.63 \mathrm{~N} 170.25 \mathrm{E}), 29 . \mathrm{VI} ., 11-$ 18.VII.2011, O.A. Khruleva (3 $O^{7} \sigma^{7}, 5$ 우, in ZMUM); Apapel'gin River (68.8N 170.65E), 5.VII.2011, O.A. Khruleva (1 $0^{x}, 2$ 우, in ZMUM); lower reaches of the Anadyr River (64.83N 175.96E), 5 m., 29.VII.2013, A. Barkalov (27 $\sigma^{7} \sigma^{7}, 10$ 웅, in ZMUM and ISEA); Meynypil'gyno env. $(62.567 \mathrm{~N} 177.033 \mathrm{E}, 62.5385 \mathrm{~N}$ 177.0519E), 6-14.VII.2010, 10-13.VII.2011, 20 and 22.VII.2013, P.C. Tomkovich (5 $0^{7} \sigma^{7}, 1$, in ZMUM); Kamchatka Kray: Lopatka Cape (50.8758N 156.6660E), 9-10.IX.1987, L. Lobkova $\left(42 \bigcirc^{7} \bigcirc^{7}, 23\right.$ 우, in ZMUM); Bering I., Nikol'skoe $(55.2132 \mathrm{~N}$ 166.0005E), 14.IX.2005, L. Lobkova (3 $\sigma^{\top} \sigma^{7}, 2$ 우, in ZMUM); Karaginskiy I. (58.883N 163.833E), mouth of the Giunvayam River, 18-26.VII.2008, O.A. Khruleva (1 $\mathrm{O}^{7}, 2$ 우, v IEE); Ozernovskiy (51.4886N 156.5023E), 12.VIII.1987, L. Lobkova (3 우, in ZMUM); Mednyy I., Preobrazhenskoe (54.7910N 167.5777E), 30.VIII.1953, S. Marakov (2 $\sigma^{7} \sigma^{7}$, in ZMUM); Magadan Oblast: Sokol env. (59.92N 150.71E), 11-19.VII.2014, N. Vikhrev (2 $\sigma^{7} \sigma^{7}$, in ZMUM).

DISTRIBUTION. Russia: Amur Oblast, Chukotka, Kamchatka Kray, Magadan Oblast, Sakhalin Oblast (Kuril Is. [Gorodkov, 1986]); european part of Russia, Siberia. - Europe (widespread), Asia (Mongolia), North America.

\section{Scathophaga hadleyi Ozerov, 2013}

This species was described from Tserkovnaya Bay (43.75N 146.70E), Shikotan I., Kuril Islands [Ozerov, 2013: 85]. Holotype is kept in ZMUM.

DISTRIBUTION. Russia: Sakhalin Oblast (Kuril Is.).

\section{Scathophaga incola (Becker, 1900)}

The species was registered for the Far East by Gorodkov [1986: 31] without specifying the place of collecting.

MATERIAL EXAMINED. Amur Oblast: Zeyskiy Reserve, “34 km" Cordon (53.9899N 127.0735E), 24 and 27.VII.1981, A.L. Ozerov (2 $\mathrm{O}^{7} \sigma^{7}$, in ZMUM); Zeyskiy Reserve, "52 km" Cordon (54.0873N 126.8713E), 14.VIII.1982, A. Shatalkin (1 9 , in ZMUM); Chukotka: Apapel'gin River (68.8N 170.65E), 5.VII.2011, O.A. Khruleva (1 $\mathrm{O}^{7}$, in ZMUM); Meynypil'gyno env. $(62.5385 \mathrm{~N}$ 177.0519E), 9.VII.2013, P.S. Tomkovich (1 9 , in ZMUM); lower reaches of the Anadyr River (64.83N 175.96E), 5 m., 28.VII.2013, O. Khruleva ( $1 \mathrm{O}^{7}$, in ZMUM); Magadan Oblast: $(59.5682 \mathrm{~N}$ 150.8091E), 28.VII.1963, Zhelokhovtsev (1 $\mathrm{O}^{\mathrm{T}}$, in ZMUM); Sokol env. (59.92N 150.71E), 11-19.VII.2014, N. Vikhrev (1 $\sigma^{7}$, in ZMUM); Primorskiy Kray: Kamenushka (43.6342N 132.2220E), 6.IX.1984, A.L. Ozerov (1 $\sigma^{7}$, in ZMUM).

DISTRIBUTION. Russia: Amur Oblast, Chukotka, Magadan Oblast, Primorskiy Kray; north of european part of Russia, Siberia. - Europe (Scandinavia), North America.

\section{Scathophaga intermedia (Walker, 1849)}

The species was registered for the Far East by Gorodkov [1986: 31] on "sea coast".

MATERIAL EXAMINED. Kamchatka Kray: Lopatka Cape $(50.8758 \mathrm{~N} 156.6660 \mathrm{E}), 24$. VIII.1987, L. Lobkova (13 $\sigma^{7} \sigma^{7}, 1$, in ZMUM); Bering I., Nikol'skoe (55.2132N 166.0005E), 14.IX.2005, L. Lobkova (6 $\sigma^{7} \sigma^{7}, 3$ +9 , in ZMUM); Bering I., Staraya Gavan' (55.1887N 166.2442E), 2.VII.1988, L. Lobkova, (11 $\mathcal{O}^{7}, 3$ 우, in ZMUM); Karaginskiy I. (58.883N 163.833E), mouth of the Giunvayam River, 25-26.VII.2008, O.A. Khruleva (40 $\triangle^{7} O^{7}, 38$ 우, in ZMUM); Bering I., northwest rookery of seals (55.2851N 165.7558E), 17.VIII.1977, Yu.D. Bodrova (1 $\bigcirc^{7}, 1$, in IBSS); Bering I., Stolovaya Montain (55.2526N 166.0430E), 20.VII.1988, A.N. Pegova (6 $\bigcirc^{7} \sigma^{7}, 5$ 우 , in ZMUM); Mednyy I. (54.5067N 168.0916E), 18-22.VII.1953, S. Marakov (1 O $\mathrm{O}^{7}$, in ZMUM); Magadan Oblast: Nagaev Bay (59.53N 150.76E), 2022.VII.2014, N. Vikhrev (10 $O^{7} \sigma^{7}, 2$ $ᄋ+$, in ZMUM); Primorskiy Kray: Kedrovyy (43.0368N 131.5255E), 20.IX.1993, I. Pilipenko (1 $\sigma^{7}$, in ZMUM); Perevoznaya Bay $(43.0396 \mathrm{~N} 131.5613 \mathrm{E})$, 20.IX.1993, I. Pilipenko (1 $\sigma^{\top}, 1$, in ZMUM); Sakhalin Oblast: Kuril Islands, Onekotan I., Nemo Bay (49.6130N 154.8188E), 4.VIII.1996, A. Leley (1 9 , in ZMUM); Kuril Islands, Paramushir I., Vasil'ev Bay (50.0555N 155.3534E), 16.VIII.1996, A. Leley, S. Storozhenko (2 $0^{7} \mathrm{O}^{7}$, in ZMUM); Kuril Islands, Ushishir Is, Yankicha I. (47.5186N 152.8119E), 1.VIII.1997, A. Leley, S. Storozhenko ( 1 +, in ZMUM); Kuril Islands, Ushishir I., Ryponkicha I. (47.5402N 152.8372E), 2.VIII.1997, A. Leley, S. Storozhenko (2 $0^{7} \mathrm{O}^{7}$, in ZMUM); Kuril Islands, Shumshu I. (50.7486N 156.3438E), 8.VIII.1997, A. Leley, S. Storozhenko (1 $\sigma^{7}$, in ZMUM); Kuril Islands, Paramushir I., Rifovaya Bay (50.4953N 156.1118E), 30.VII.1999, A. Leley, S. Storozhenko (1 O , in ZMUM); Kuril Islands, Moneron I. (46.2503N 141.2350E), 24.VII.2004, A. Leley, S. Storozhenko (1 $0^{2}$, in ZMUM).

DISTRIBUTION. Russia: Kamchatka Kray, Magadan Oblast, Primorskiy Kray, Sakhalin Oblast (Kuril Is.). — North America.

\section{Scathophaga lapponica (Ringdahl, 1920)}

The species was firstly registered for the Far East from Commander Is. by Gorodkov [1986: 32].

MATERIAL EXAMINED. Amur Oblast: Zeyskiy Reserve, "52 km" Cordon (54.0873N 126.8713E), 7.VII.1982, A. Shatalkin $\left(1 O^{7}\right.$, in ZMUM). 
DISTRIBUTION. Russia: Amur Oblast, Kamchatka Kray; european part of Russia, Siberia. - Europe (Czech Republic [Šifner, 2003], Finland, Sweden), Asia (Mongolia), North America.

\section{Scathophaga litorea (Fallén, 1819)}

MATERIAL EXAMINED. Chukotka: Meynypil'gyno env. (62.5385N 177.0519E), 3-13.VII.2012, P.S. Tomkovich (1 $\sigma^{7}$, in ZMUM); Apapel'gin River (68.8N 170.65E), 5 and 22.VII.2011, O.A. Khruleva (2 $\sigma^{7} \sigma^{7}, 6$ 우, in ZMUM); Uelen (66.1605N $169.8219 \mathrm{~W}), 25$. VII.1972, Yu.D. Bodrova (3 $\sigma^{7} \sigma^{7}$, in IBSS); Kamchatka Kray: Mednyy I., Glinka Bay (54.5866N 167.9643E), 5.VIII.1988, A.N. Pegova (1 $\mathrm{O}^{7}$, in ZMUM); Mednyy I., Preobrazhenskoe (54.7910N 167.5777E), 25.VII.-31.VIII.1953, S. Marakov $\left(5 \sigma^{7} \sigma^{7}, 3\right.$, 3 , in ZMUM); Khabarovsk Kray: Vanino (49.11N 140.31E), 9.VI.2014, N. Vikhrev (15 $\sigma^{7} \sigma^{7}$, in ZMUM); Magadan Oblast: Nagaev Bay (59.53N 150.76E), 2022.VII.2014, N. Vikhrev (6 $\sigma^{7} \sigma^{7}$, in ZMUM); Sakhalin Oblast: Kuril Islands, Shikotan I. Tserkovnaya Bay $(43.75 \mathrm{~N}$ 146.70E), 23-31.V. and 10-14.VI.2012, Yu. Sundukov (5 $\sigma^{7} \sigma^{7}, 4$ 우, in ZMUM); Sakhalin I., Elizaveta Bay $(54.4112 \mathrm{~N} 142.6979 \mathrm{E})$, 7.VIII.2001, A. Leley (1 $0^{7}$ in ZMUM)

DISTRIBUTION. Russia: Chukotka, Kamchatka Kray, Khabarovsk Kray, Magadan Oblast, Sakhalin Oblast (Kuril Is., Sakhalin I.) (first record for Russian Far East and firstly for Pacific coast); european part of Russia. - Europe, North America (Atlantic coast).

\section{Scathophaga mollis (Becker, 1894)}

Scathophaga sychevskayae Ozerov, 2010d: 165 — syn.n. MATERIAL EXAMINED. Magadan Oblast: Susuman (62.7772N 148.1415E), 13.VII.1963, Zhelokhovtsev (1 $\sigma^{7}$, in ZMUM).

DISTRIBUTION. Russia: Magadan Oblast (first record for Russian Far East); Siberia. - Asia (Mongolia, China [Sun, 1996]), North America.

\section{Scathophaga multisetosa (Holmgren, 1883)}

The species was registered for the Far East by Gorodkov [1986: 33] without specifying the place of collecting.

MATERIAL EXAMINED. Chukotka: Vrangel I., Somnitel'nye Montans (71.0N 179.5333E), 13.VI.-14.VIII.2006, O.A. Khruleva (5 $0^{7} O^{7}, 3$ O , in ZMUM); Vrangel I., Mamontovaya River (70.9833N 179.75E), 26.VI--19.VII.2011, A.A. Rodionov ( $1 \sigma^{7}$, in ZMUM); Vrangel I., Neizvestnaya River (71.2166N 179.3166E), 3-6.VII.2007, O.A. Khruleva (1 O ${ }^{7}$, in ZMUM); Pevek env. (69.7N 170.35E), 27.VI.-7.VII.2006, O.A. Khruleva (1 $0^{7}$, in ZMUM).

DISTRIBUTION. Russia: Chukotka; north of european part of Russia, Siberian sea coast. - North America.

\section{Scathophaga nigripalpis (Becker, 1907)}

The species was firstly registered for the Far East by Gorodkov [1986: 33] from Olutorsky Bay.

MATERIAL EXAMINED. Chukotka: Meynypil'gyno env. (62.567N 177.033E), 23-27.VI.2011, P.S. Tomkovich (1 O', in ZMUM).

DISTRIBUTION. Russia: Chukotka; european part of Russia [Gorodkov, 1970], Siberia. — North America.

\section{Scathophaga obscura (Fallén, 1819)}

The species was firstly registered for the Far East by Gorodkov [1986: 33] from Kuril Islands.

MATERIAL EXAMINED. Amur Oblast: town Zeya $(53.7485 \mathrm{~N}$ 127.2614E), 9 and 20.VII., 7.VIII.1981, A. Ozerov $\left(20^{7} \sigma^{7}, 19\right.$, in ZMUM); Zeyskiy Reserve, "34 km" Cordon (53.9899N 127.0735E), 24.VII.1981, A. Shatalkin (1 + , in ZMUM); Zeyskiy Reserve, " 52 km" Cordon (54.0873N 126.8713E), 7.VIII.1982, M. Krivosheina (1 + , in ZMUM); Chukotka: Apapel'gin River (68.8N 170.65E), 5.VII.2011, O.A. Khruleva ( $1 \sigma^{2}$, in ZMUM); Primorskiy Kray: Bikin River, 22 $\mathrm{km}$ above the mouth of Svetlovodnaya River (46.6166N 137.0543E), 14.VIII.1980, V. Zlobin (5 $\sigma^{7} \sigma^{7}, 3$ 우, in ZISP); Kamenushka (43.6342N 132.2220E), 13 and 27.VIII.1983, 18 and 25.VII.1984, 23.IX.1987, A.L. Ozerov, A. Shatalkin (4 $\sigma^{7} \sigma^{7}, 4$ OP, in ZMUM); Anuchino env. (43.95N 133.05E), 20-21.VI.2014, N. Vikhrev (2 $\sigma^{7} \sigma^{7}$, in ZMUM); Kamenushka (43.62N 132.23E), 22-24.VI.2014, N. Vikhrev ( $2 \bigcirc^{\top} \sigma^{\top}, 4$ +ᄋ , in ZMUM); Lotos Lake (42.46N 130.64E), 1-3.VII.2014, N. Vikhrev (1 $\bigcirc^{7}$, in ZMUM).

DISTRIBUTION. Russia: Amur Oblast, Chukotka, Primorskiy Kray, Sakhalin Oblast (Kuril Is.); european part of Russia, Siberia. - Europe, Asia (Mongolia), North America.

\section{Scathophaga obscurinervis (Becker, 1900)}

The species was registered for the Far East by Gorodkov [1986: 33] without specifying the place of collecting.

MATERIAL EXAMINED. Chukotka: Meynypil'gyno env. (62.5385N 177.0519E), 9.VII.2013, P.S. Tomkovich (1 $\sigma^{7}$, in ZMUM).

DISTRIBUTION. Russia: Chukotka; european part of Russia, Siberia. - Europe (Scandinavia), North America.

\section{Scathophaga stercoraria (Linnaeus, 1758)}

Registered for the Far East (e.g. Gorodkov [1981, 1986], Ozerov [2009b]).

MATERIAL EXAMINED. Amur Oblast: Tynda (55.1455N 124.7330E), 25 and 31.VII.1977, G. Veselkin ( $2 \sigma^{7} \sigma^{7}$, in ZMUM); town Zeya (53.7485N 127.2614E), 14 and 20.VI., 3 and 10.VIII.1981, A. Ozerov, (2 $0^{\top} \sigma^{\top}, 2$ ㅇ, in ZMUM); Zeyskiy Reserve, "52 km" Cordon (54.0873N 126.8713E), 14.VIII.1981, A.L. Ozerov, A. Shatalkin ( $2 \mathrm{O}^{7} \mathrm{O}^{7}$, in ZMUM); Gornyy env. (50.7680N 136.4233E), 28.V.1988, Mutin (1 $\bigcirc^{7}$, in IBSS); Chukotka: Anadyr' (airport) (64.7343N 177.5035E), 3.VI.1993, P.S. Tomkovich (1 9 , in ZMUM); lower reaches of the Anadyr River $(64.83 \mathrm{~N} 175.96 \mathrm{E}), 5 \mathrm{~m}$., 31.VII.2013, A. Barkalov (1 O', in ISEA); Jewish Autonomus Oblast: Birofeld (48.5N 132.9E), 28-31.VI.2013, I. Melnik (1 $\sigma^{7}$, in ZMUM); Kamchatka Kray: Kozlov Cape (54.8344N 162.1506E), 4 and 16.VII.1988, L. Lobkova (6 $0^{7} \sigma^{7}, 1$, in ZMUM); Zhupanovo (54.0822N 159.9811E), 4.VII.1988, L. Lobkova (1 O', in ZMUM); Karaginskiy I. (58.883N 163.833E), mouth of the Giunvayam River, 25-26.VII.2008, O.A. Khruleva (1 $\sigma^{7}, 1$, in ZMUM); Mednyy I., Preobrazhenskoe (54.7910N 167.5777E), 30.VIII.1953, S. Marakov (1 $\sigma^{7}, 4$ $9+$, in ZMUM); Bering I., Staraya Gavan' (55.1887N 166.2442E), 4.VIII.1988, A.N. Pegova (1 $\sigma^{7}$, in ZMUM); Khabarovsk Kray: Khabarovsk (48.4874N 135.0767E), 17.VI.1931, V. Pereleshina (1 9 , in ZMUM); Nikolaevsk-na-Amure (53.1478N 140.7218E), 1.VII.1978, G. Veselkin ( 1 \% , in ZMUM); Vanino (49.11N 140.31E), 9.VI.2014, N. Vikhrev (1 $\sigma^{7}$, in ZMUM); Magadan Oblast: Stekolnyy (60.06N 150.75E), 17.VII.2014, N. Vikhrev (1 $\bigcirc^{7}$, in ZMUM); Primorskiy Kray: Arsen'ev (44.1361N 133.2816E), 28.VI.1986, Makarkin (1 $\bigcirc^{7}, 5$ 우, in IBSS); Sudzuchinskiy [=Lazovskiy] Reserve, Tachingou (43.0236N 134.1363E), 11.IX.1948, Gussakovskiy (1 $\sigma^{\top}$, in ZMUM); okr. oz. Khasan 
(42.4245N 130.6511E), 13.VII.1962, L. Zimina (2 ○ ఠ , in ZMUM); Lazo env. (43.3812N 134.8949E), 21.IX.1987, A.L. Ozerov (1 ऽ, in ZMUM); Kamenushka (43.6342N 132.2220E), 25.V.1985, 19.IX.1990, A. Antropov, A.L. Ozerov (1 $\sigma^{7}, 1$, in ZMUM); Spassk (44.6000N 132.8166E), 1.VII.1961, Zhelokhovtsev (1 $\sigma^{7}$, in ZMUM); Vladivostok env., Okeanskaya (43.2339N 132.0058E), 3.VII.1937, N. Shutova ( $1 \sigma^{7}$, in ZMUM); Sakhalin Oblast: Kuril Islands, Kunashir I., caldera of Golovnin Volkano (43.8438N 145.5050E), 12 24.VII.2008, I. Mel'nik (1 $\sigma^{7}$, in ZMUM); Kunashir I., Mendeleev Volkano env. (43.9610N 145.7290E), 27.VII.1985, S. Churkin (1 + , in ZMUM); Kuril Islands, Kunashir I., caldera of Golovnin Volcano (43.859N 145.505E), 7-9.VI.2013, Yu. Sundukov (12 $\bigcirc^{7} \sigma^{7}, 6$ 오 in ZMUM); Kuril Islands, Kunashir I., Kosmodem'yansk (44.0955N 145.8923E), 24.VIII.1964, Azarova (1 ऽ, in IBSS); Kuril Islands, Kunashir I., Ivanovskyi Cape (43.828N 145.400E), 23-29.V.2013, 11-17.VI.2013, Yu. Sundukov ( $9 \sigma^{\top} \sigma^{\top}, 4$ 우 in ZMUM); Kuril Islands, Kunashir I., Filatovka River (44.186N 146.025E), 25 27.VI.2013, Yu. Sundukov (1 $\sigma^{7}$, in ZMUM); Kuril Islands, Kunashir I., the mouth of the stream Bystryi (43.787N 145.422E), 27.IX.2013, Yu. Sundukov ( 1 , in ZMUM); Kuril Islands, Kunashir I., YuzhnoKurilsk (44.026N 145.862E), 6 and 22.VII.2013, Yu. Sundukov (3 $\sigma^{7} \sigma^{7}, 3$ 우 in ZMUM); Sakhalin I., Il'inskoe (47.9919N 142.2013E), 14.VI.1950, N. Violovich ( 1 + , in ZMUM); Sakhalin I., Starodubskoe (47.4114N 142.8046E), 1.VIII.1972, I. Sukacheva (1 $\sigma^{7}$, in ZMUM); Kuril Islands, Shikotan I., Tserkovnaya Bay (43.75N 146.70E), 2331.V., 10-14.VI., 23-30.VIII., and 25-30.IX.2012, Yu. Sundukov (3 $\sigma^{\top} \sigma^{\top}, 3$ +O, in ZMUM); Sakhalin I., Kuznetsovo (46.0465N 141.9236E), 19.VII.1953, G. Gusev (3 $\sigma^{\top} \sigma^{7}$, in ZMUM); Sakhalin I., Tymovo env. (51.1281N 142.6751E), 1.VI.1979, A. Veselkin (2 9o, in ZMUM).

DISTRIBUTION. Russia: Amur Oblast, Chukotka, Jewish Autonomus Oblast, Kamchatka Kray, Khabarovsk Kray, Magadan Oblast, Primorskiy Kray, Sakhalin Oblast (Kuril Is., Sakhalin I.); widespread on all territory of european part of Russia and Siberia. - widespread in Palaearctic and Neartic Regions, Oriental Region (China, India, Nepal [Vockeroth, 1977; Sun, 1996]).

\section{Scathophaga suilla (Fabricius, 1794)}

The data on distribution of this species for the Far East was given by Gorodkov [1980, 1986].

MATERIAL EXAMINED. Amur Oblast: Nukzha River (56.5741N 121.6527E), 18.VI.1976, Soboleva (1 $\sigma^{7}$, in IBSS); Komsomol'sk-na-Amure, Silinsky Park (50.5736N 137.0392E), 29.V.1985, Mutin ( 1 , in IBSS); town Zeya (53.7485N 127.2614E), 11.IX.1981 A. Shatalkin ( $\sigma^{\top}, 1$, in ZMUM); Chukotka: lower reaches of the Anadyr River (64.83N 175.96E), 5 m., 31.VII.2013, A. Barkalov (1 $\sigma^{7}$, in ISEA); Sakhalin Oblast: Kuril Islands, Kunashir I., Mendeleevo (43.9583N 145.6830E), 2.VIII.1975, Berezantsev $\left(1 \sigma^{7}\right.$, in IBSS).

DISTRIBUTION. Russia: Amur Oblast, Chukotka, Sakhalin Oblast (Kuril Is.); european part of Russia, Siberia. — Europe (widespread), Asia (Kazakhstan, Mongolia, China), Africa (Syria [Šifner, 1981]), North America.

\section{Scathophaga taeniopa Rondani, 1867}

The species was registered for the Far East by Gorodkov [1986: 34] without specifying the place of collecting.

MATERIAL EXAMINED. Khabarovsk Kray: Khabarovsk (48.6N 135.1E), 2-6. and 13.VI.2014, N. Vikhrev (1 9 , in ZMUM); Magadan Oblast: Sokol env. (59.92N 150.71E), 11-19.VII.2014, N. Vikhrev (3 $\sigma^{7} \sigma^{7}$, in ZMUM); Stekolnyy (60.06N 150.75E), 17.VII.2014, N. Vikhrev (1 $\sigma^{7}$, in ZMUM); Primorskiy Kray: Khanka Lake (45.06N 131.99E), 15-19.VI. and 4-6.VII.2014, N. Vikhrev $(1+$, in ZMUM).
DISTRIBUTION. Russia: Khabarovsk Kray, Magadan Oblast, Primorskiy Kray; european part of Russia, Siberia. - Europe, Asia (China [Sun, 1996]).

\section{Scathophaga tinctinervis (Becker, 1894)}

MATERIAL EXAMINED. Primorskiy Kray: Khanka Lake (45.06N 131.99E), 15-19.VI. and 4-6.VII.2014, N. Vikhrev (1 O7, 1 , in ZMUM); Spassk-Dalnyy (44.58N 132.85E), 15.VI.2014, N. Vikhrev (1 $\mathrm{O}^{\top}$, in ZMUM);

DISTRIBUTION. Primorskiy Kray (first record for Russian Far East); Leningradskaya Oblast [Gorodkov, 1986]. - Europe.

\section{Scathophaga varipes (Holmgren, 1883)}

The species was firstly registered for the Far East by Gorodkov [1986: 34] from Vrangel Island.

MATERIAL EXAMINED. Chukotka: Ayon I. (69.8321N 168.6578E), 9.VII.1958, V. Lebedev (4 $\sigma^{7} \sigma^{7}, 1$ ㅇ, in ZMUM); Vrangel I., Neozhidannaya River (71.0166N 179.1333E), 10.VI.27.VII.2006, O.A. Khruleva, (1 9 , in ZMUM); Vrangel I., Krasnyy Flag River (71.2666N 179.85E), 16-27.VII.2011, S.S. Lantsov, (2 $\mathrm{O}^{7} \mathrm{O}^{2}$, in ZMUM)

DISTRIBUTION. Russia: Chukotka; european part of Russia, Siberia. - North America.

\section{Scatomyza mellipes (Coquillett, 1899)}

eoa Ozerov, 2007b: 2 (Scathophaga). Synonymized by Ozerov [2009a: 426]. This species was described from Amur Oblast and Primorskiy Kray; holotype is kept in ZMUM.

The species was registered for the Far East by Gorodkov [1986: 32] without specifying the place of collecting. MATERIAL EXAMINED. Amur Oblast: Zeyskiy Reserve, "52 km" Cordon (54.0873N 126.8713E), 13, 19 and 29.VIII.1981, A.L. Ozerov, A. Shatalkin (5 $\sigma^{\top} \sigma^{7}, 1$, in ZMUM); 5-6 km above Ekimchan (53.0853N 132.9742E), 31.VIII.2006, A.B. Ryvkin (7 $\sigma^{7} \sigma^{7}, 2$ 우, in ZMUM); Primorskiy Kray: Kamenushka $(43.6342 \mathrm{~N}$ 132.2220E), 18 and 21.IX.1987, A. Ozerov, A. Antropov (1 $\sigma^{7}, 2$ + , , in ZMUM); Lazovskiy Reserve, basin of Bystrushka River, second Sobolinyy Spring (43.18N 134.11E), 15-17.VI.2007, Yu. Sundukov (1 $\mathrm{O}^{7}$, in ZMUM); Sudzuchinskiy [=Lazovskiy] Reserve, Tachingou (43.0236N 134.1363E), 30.IX., 2-9.X.1948, Gussakovskiy (4 $\sigma^{7} \sigma^{\top}, 2$ 우, in ZMUM);

DISTRIBUTION. Russia: Amur Oblast, Primorskiy Kray. - Asia (China [Sun, 1996], Japan [Vockeroth, 1977], Korea [Suh et al., 2007] Vietnam [Ozerov \& Krivosheina, 2011]).

\section{Scatomyza scybalaria (Linnaeus, 1758)}

The species was registered for the Far East by Gorodkov [1986: 33] without specifying the place of collecting. MATERIAL EXAMINED. Amur Oblast: town Zeya (53.7485N 127.2614E), 3.VIII., 20.VII. and 3.IX.1981, A.L. Ozerov, A. Shatalkin, O. Gorbunov ( $2 \sigma^{7} 0^{7}, 3$ 우, in ZMUM); Khabarovsk Kray: Kharpichan (51.2938N 136.5246E), 24.VII.1976, G. Veselkin (6 $0^{7} \sigma^{7}$, in ZMUM); Izvestkovyy (50.2575N 136.6487E), 31.VII.1978, G. Veselkin (1 $\sigma^{7}$, in ZMUM); Vanino (49.11N 140.31E), 9.VI.2014, N. Vikhrev (1 o', in ZMUM); Primorskiy Kray: Khasan Lake env. (42.4245N 130.6511E), 1213.VII.1962, L. Zimina (3 $\mathrm{O}^{7} \mathrm{O}^{7}$, in ZMUM); Sudzuchinskiy [=Lazovskiy] Reserve, Tachingou (43.0236N 134.1363E), 30.IX., 29.X.1948, Gussakovskiy (1 + , in ZMUM); Spassk (44.6000N 132.8166E), 4-26.VI., 4.VII. and 3.VIII.1961, Zhelokhovtsev (2 $\sigma^{7} \sigma^{7}, 4$ 우 , in ZMUM); Lazo env. (43.3812N 1334.8949E), 30.VII. 
and 3.VIII.1986, 17.VIII.1987, (5 O $^{7} 0^{7}, 1$ 1 , in ZMUM); Kamenushka (43.6342N 132.2220E), 30.VII., 9 and 17.VIII.1983, 25.V.1985, 17.IX.1990, A.L. Ozerov, A. Shatalkin, A. Antropov ( $4 \mathrm{O}^{7} \mathrm{O}^{7}, 2$ 우, in ZMUM); Khanka Lake env. (44.8666N 132.8104E), 9.VI.1961 (6 $\sigma^{7} \sigma^{7}, 2$ 우, in ZMUM); Khanka Lake (45.06N 131.99E), 15-19.VI. and 4-6.VII.2014, N. Vikhrev (1 + , in ZMUM); Sakhalin Oblast: Kuril Islands, Kunashir I., Nazarov Cape, 30.VII.1974, Petrova (1 $\mathrm{O}^{2}$, in IBSS); Kuril Islands, Kunashir I., Mendeleev Volkano env. (43.9610N 145.7290E), 27.VII.1985, S. Churkin (1 $\sigma^{7}$, in ZMUM).

DISTRIBUTION. Russia: Amur Oblast, Khabarovsk Kray, Primorskiy Kray, Sakhalin Oblast (Kuril Is.); european part of Russia, Siberia. - Europe (widespread), Asia (China [Sun, 1996], Korea [Suh et al., 2007]).

\section{Spaziphora hydromyzina (Fallén, 1819)}

MATERIAL EXAMINED. Kamchatka Kray: (56.3761N 160.6861E), 30.VII.1930, V.I. Sychevskaya (1 $\sigma^{7}, 1$, in ZMUM).

DISTRIBUTION. Russia: Kamchatka Kray (first record for Russian Far East); european part of Russia, Siberia. - Europe (widespread), Asia (Kazakhstan, Mongolia).

\section{Spaziphora tomkovichi Ozerov, 2012}

This species was described from Meynypil'gyno env. (62.5385N 177.0519E), Chukotka [Ozerov, 2012: 427]; holotype is kept in ZMUM.

MATERIAL EXAMINED. Chukotka: Meynypil'gyno env. (62.5385N 177.0519E), 26-29.VI.2012, P.S. Tomkovich (1 $\sigma^{7}$, in ZMUM); Khabarovsk Kray: Vanino (49.11N 140.31E), 9.VI.2014, N. Vikhrev (2 $\mathrm{O}^{7} \mathrm{O}^{7}$, in ZMUM); Primorskiy Kray: Khanka Lake (45.06N 131.99E), 15-19.VI. and 4-6.VII.2014, N. Vikhrev (21 $0^{7} 0^{7}, 7$ 우, in ZMUM).

DISTRIBUTION. Russia: Chukotka, Khabarovsk Kray, Primorskiy Kray.

\section{Trichopalpus fraternus (Meigen, 1826)}

MATERIAL EXAMINED. Primorskiy Kray: Kamenushka (43.6342N 132.2220E), 11.VII.1984, A. Shatalkin (1 $0^{7}$, in ZMUM), VII.1984, A.L. Ozerov ( 1 \%, in ZMUM); Khanka Lake (45.06N 131.99E), 15-19.VI. and 4-6.VII.2014, N. Vikhrev (14 O $^{7} \mathrm{O}^{7}, 9$ 우우, in ZMUM).

NOTE. There is some marked variation in the colour of femora. Ussualy femora of this species are dark brown or black at middle and yellow in apical and basal parts, with black apex in mid and hind femora. More than half specimens from Khanka Lake have femora yellow, except the most apices of mid and hind femora.

DISTRIBUTION. Russia: Primorskiy Kray (first record for Russian Far East); european part of Russia [Gorodkov, 1970]. — Europe (Scandinavia), North America.

Trichopalpus (Huckettia) nearcticus (Vockeroth, 1987)

MATERIAL EXAMINED. Chukotka: Meynypil'gyno env. (62.5385N 177.0519E), 15.VII.2014, P.S. Tomkovich (9 $\sigma^{7} \sigma^{7}, 7$ o+ , in ZMUM).

DISTRIBUTION. Russia: Chukotka (first record for Russian Far East); Yakutia [Engelmark, 1999]. — North America.

\section{Trichopalpus nigribasis (Curran, 1927)}

MATERIAL EXAMINED. Amur Oblast: town Zeya (53.7485N 127.2614E), 28.VI.1978, A. Shatalkin (1 $\mathrm{O}^{\top}$, in ZMUM); Primorskiy Kray: Kamenushka (43.6342N 132.2220E), 8.VIII.1983, A.L. Ozerov (1 9 , in ZMUM).

DISTRIBUTION. Russia: Amur Oblast, Primorskiy Kray (first record for Russian Far East). Europe (Scandinavia), North America.

Trichopalpus obscurellus (Zetterstedt, 1846)

MATERIAL EXAMINED. Chukotka: Meynypil'gyno env.

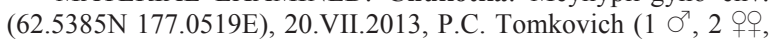
in ZMUM).

DISTRIBUTION. Russia: Chukotka (first record for Russian Far East). — Europe (Scandinavia), North America.

\section{Trichopalpus punctipes (Meigen, 1826)}

The species was registered for the Far East by Gorodkov [1986: 28, as Chaetosa punctipes] without specifying the place of collecting.

MATERIAL EXAMINED. Amur Oblast: town Zeya (53.7485N 127.2614E), 12.VI.-19.VII.1978, 29.VI.-16.VII. and 14.IX.1981, 14.VIII.1982, A. Shatalkin (18 $0^{7} \sigma^{7}, 17$ 우, in ZMUM); 8.VIII.1981, 17.VII.1982, A. Ozerov, M. Krivosheina (2 $0^{7} \mathrm{O}^{7}, 1$ \%, in ZMUM); Zeyskiy Reserve, "34 km" Cordon (53.9899N 127.0735E), 10.14.VII.1981, A.L. Ozerov, M. Krivosheina ( $60^{\top} \sigma^{\top}, 3$ 우, in ZMUM); Zeyskiy Reserve, "52 km" Cordon (54.0873N 126.8713E), 6.VII.1982, A.L. Ozerov (3 $\sigma^{7} \sigma^{7}$, in ZMUM), 26-27.VI. and 7.VII.1982, M. Krivosheina (1 $\odot^{7}, 2$ 우, in ZMUM); $3 \mathrm{~km} \mathrm{SW}$ of Norsk, Al'dikon River near of mouth, 200 m (52.3264N 129.8519E), 21.VIII.2006, A.B. Ryvkin (4 $\bigcirc^{7} \sigma^{7}, 1$, in ZMUM); Nukzha River (56.5741N 121.6527E), 18.VI.1976, Soboleva (1 O', in IBSS); Chukotka: Meynypil'gyno env. (62.5385N 177.0519E), 26-29.VI. and 3-13.VII.2012, P.C. Tomkovich (4 $0^{7} 0^{7}, 1$ 9, in ZMUM); lower reaches of the Anadyr River (64.83N 175.96E), 5 m, 18-29.VII.2013, A. Barkalov (4 $\sigma^{7} \sigma^{7}, 2$ O, in ZMUM and ISEA); Kamchatka Kray: Karaginskiy I. (58.883N 163.833E), mouth of the Giunvayam River, 25-26.VII.2008, O.A. Khruleva (4 우, in ZMUM); Uzon (54.4877N 159.9772E), 9.VII.1987, L. Lobkova (1 $\sigma^{7}$, in ZMUM); Khabarovsk Kray: Khabarovsk (48.6N 135.1E), 2-6.VI.2014, N. Vikhrev ( $2 \mathrm{O}^{7} \sigma^{7}, 1$ \%, in ZMUM); Manoma River (49.44N 137.41E), 8.VI.2014, N. Vikhrev (1 $\sigma^{7}, 1$ \% , in ZMUM); Vanino (49.11N 140.31E), 9.VI.2014, N. Vikhrev (1 $\sigma^{7}$, in ZMUM); Magadan Oblast: Sokol env. (59.92N 150.71E), 11-19.VII.2014, N. Vikhrev (1 $\mathrm{O}^{T}$, in ZMUM); Primorskiy Kray: Kamenushka (43.6342N 132.2220E), 4.VIII.1984, A. Shatalkin (1 + , in ZMUM), 918.VIII.1983, 24.VII.1984, 3.VII.1985, A.L. Ozerov (4 $\sigma^{7} \sigma^{7}$, 2 우, in ZMUM); Khanka Lake (45.06N 131.99E), 15-19.VI.2014, N. Vikhrev (4 $\bigcirc^{7} \sigma^{7}$, in ZMUM); Kamenushka (43.62N 132.23E), 22 24.VI.2014, N. Vikhrev (1 O), in ZMUM); Gornye Kluchi (45.25N 133.50E), 6-7.VII.2014, N. Vikhrev (1 $\sigma^{7}$, in ZMUM); Luchegorsk (46.47N 134.32E), 8.VII.2014, N. Vikhrev (1 O'7, in ZMUM); Sakhalin Oblast: Kuril Islands, Kunashir I., Tretyakovo (43.9913N 145.6555E), 21-29.VII.2011, Proschelykin, Loktionov (1 9 , in ZMUM); Sakhalin I., $13 \mathrm{~km}$ N of Nevelsk (46.5516N 141.8416E), 16.VII.2011, Proschelykin, Loktionov (1 $\mathrm{O}^{\top}$, in ZMUM); Sakhalin I., Holmsk (47.0612N 142.0537E), 26.VI.1950, N. Violovich (1 9 , in ZMUM); Sakhalin I., Il'inskoe (47.9919N 142.2013E), 4.VI.1950, N. Violovich (1 $\mathrm{O}^{7}$, in ZMUM); Sakhalin I., Moskalevo (53.5679N 142.5040E), 13.VIII.2001, A. Leley (1 $\sigma^{7}$, in ZMUM).

DISTRIBUTION. Russia: Amur Oblast, Chukotka, Kamchatka Kray, Khabarovsk Kray, Magadan Oblast, Primorskiy Kray, Sakhalin Oblast (Kuril Is., Sakhalin I.); european part of Russia, Siberia. - Europe (widespread), Asia (Mongolia), North America. 
ACKNOWLEDGEMENTS. We are very grateful to the following colleagues who have collected material for this study: Dr A.V. Barkalov (ISEA), Dr O.A. Khruleva (IPEE), Drs A.S. Leley, S.Yu. Storozhenko and Yu.N. Sundukov (IBSS), L.E. Lobkova (KRE), Drs P.C. Tomkovich and N.E. Vikhrev (ZMUM).

The reported study was supported by RFBR, research project No.13-04-01638 a.

\section{References}

Becker T. 1894. Dipterologische Studien. I. Scatomyzidae // Berliner Entomologische Zeitschrift. Bd.39. Heft 1. P.77-196.

Coquillett D.W. 1901. New Diptera in the U. S. National Museum // Proceedings of the United States National Museum. Vol.23. No.1225. P.593-618.

Cumming J.M., Wood D.M. 2009. Adult morphology and terminology. Pp. 9-50. In Brown B.V., Borkent A., Cumming J.M., Wood D.M., Woodley N.E., Zumbado M. (eds.). Manual of Central American Diptera. Vol. 1. National Research Council Press, Ottawa. P.9-50.

Elberg K. 1972. Cordilura remmi sp. n. a new species of Scatophagidae (Diptera) from the Far East // Acta et Commentationes Universitatis Tartuensis, Zoologia - Alaseid Toid. Vol.6. P.91-96.

Engelmark R. 1999. Dungflies (Diptera: Scathophagidae) collected by the Swedish-Russian tundra ecology expedition ' 94 , with the description of two new species; Nanna indotatum and Cochliarium sibiricum // Entomologisk Tidskrift. Arg.120. Häft 4. P.157-167.

Gorodkov K.B. 1970. [Family Scathophagidae (Cordyluridae, Scatomyzidae, Scopeumatidae)] // Bei-Bienko G.Y. (ed.). Opredelitel' nasekomykh Evropeiskoi chasti SSSR. Vol.5. Diptera, Siphonaptera. Part 2. P.440-458 [in Russian].

Gorodkov K.B. 1978. [Diptera, Scarhophagidae. Scathophaga furcata (Say, 1823)] // Arealy nasekomykh Evropeiskoy chasti SSSR. Maps 1-20. Leningrad: Nauka Publ. Map 20. P.24 [in Russian].

Gorodkov K.B. 1980. [Scathophaga suilla (Fabricius, 1794). Diptera, Scarhophagidae] // Arealy nasekomykh Evropeiskoy chasti SSSR. Atlas. Maps 21-72. Leningrad: Nauka Publ. Map 68. P.51 [in Russian].

Gorodkov K.B. 1981. [Scathophaga stercoraria (Linnaeus, 1758). Diptera, Scarhophagidae] // Arealy nasekomykh Evropeiskoy chasti SSSR. Atlas. Maps 73-125. Leningrad: Nauka Publ. Map 121. P.52 [in Russian].

Gorodkov K.B. 1986. Family Scathophagidae // Soós Á, Papp L. (eds.). Catalogue of Palaearctic Diptera. Vol.11. Scathophagidae-Hypodermatidae. Budapest: Akadémiai Kiadó. P.1141.

Hackman W. 1956. The Scatophagidae (Dipt.) of Eastern Fennoscandia // Societas pro Fauna et Flora Fennica. Fauna fennica II. Helsingforsiae. $67 \mathrm{pp}$.

Hendel F. 1930. Entomologische Ergebnisse der schwedischen Kamtchatka-Expedition 1920-1922. 28. Diptera Brachycera 2. Fam. Cordyluridae und Dryomyzidae // Arkiv för Zoologi. Bd.21A. No.18. S.1-12.

Hironaga T., Suwa M. 2005. Notes on the genus Norellisoma in Japan, with description of a new species (Diptera, Scathophagidae) // Studia dipterologica. Vol.12. No.1. P. 199-208.

McAlpine J.F. 1981. Morphology and terminology-adults // McAlpine J.F., Peterson B.V., Shewell G.E, Teskey H.J., Vokeroth J.R., Wood D.M. (coordinators). Manual of Nearctic Diptera. Vol.2. Research Branch. Agriculture Canada. Monograph 27, Ottawa. P.9-63.

Merriam Webster's Geographical Dictionary. 1997.Third Edition, Springfield. $1361 \mathrm{pp}$.

Ozerov A. L. 1993. [New palaearctic species of the genus Norellia (Diptera, Scathophagidae] // Vestnik Zoologii. No.5. P.76-93 [in Russian].
Ozerov A. L. 1996. Scathophaga exalata sp. n. (Diptera, Scathophagidae) with reduced wings from Kuril Islands // Far Eastern Entomologist. No.35. P.1-4.

Ozerov A.L. 1997. [Five new species of the genus Cordilura (Diptera, Scathophagidae) from the Far East of Russia] // Zoologicheskiy zhurnal. Vol.76. No.12. P.1424-1429 [in Russian].

Ozerov A.L. 1999a. [New genus and three new species of Scathophagidae (Diptera) from the Russian Far East] // Zoologicheskiy zhurnal. Vol.78. No.4. P.510-512 [in Russian].

Ozerov A.L. 1999b. [To the fauna of Cochliarium (Diptera, Scathophagidae)] // Zoologicheskiy zhurnal. Vol.78. No.5. P.635637 [in Russian].

Ozerov A.L. 2005. Primary types of Diptera (Insecta) in the Zoological Museum of Moscow State University (ZMUM). I. Families Acartophthalmidae, Asilidae, Carnidae, Conopidae, Dryomyzidae, Ephydridae, Lauxaniidae, Micropezidae, Milichiidae, Neottiophilidae, Pallopteridae, Piophilidae, Scathophagidae, Sepsidae // Russian Entomological Journal.Vol.14. No.2. P.125-137.

Ozerov A.L. 2006. New species of the family Scathophagidae (Diptera) from Altai and Far East of Russia // Euroasian Entomological Journal. Vol.5. No.4. P.333-336 [in Russian].

Ozerov A.L. 2007a. Four new species of dung flies (Diptera: Scathophagidae) from Russian Far East // Russian Entomological Journal. Vol.16. No.1. P.123-126.

Ozerov A.L. 2007b. New species of the genus Scathophaga Meigen (Diptera, Scathophagidae) from Russian Far East // Far Eastern Entomologist. No.107. P.1-4.

Ozerov A.L. 2007c. On Scathophagidae species (Insecta: Diptera), described by Fr. Hendel from the materials of the Swedish Kamchatka expedition 1920-1922 // Far Eastern Entomologist. No.174. P.5-8.

Ozerov A.L. 2009a. New species of Scathophagidae (Diptera) // Russian Entomological Journal. Vol.17. No.4. P.419-427.

Ozerov A.L. 2009b. [Fam. Scathophagidae] // Storozhenko S.Yu. et al. (eds.). Insects of Lazovsky Nature. Vladivostok: Dalnauka. P.379 [in Russian].

Ozerov A.L. 2010a. On the Palaearctic fauna of Norellisoma Wahlgren, 1917 (Diptera: Scathophagidae) // Russian Entomological Journal. Vol.18. No.3(2009). P.229-234.

Ozerov A.L. 2010b. Flies of the genus Parallelomma Becker in Strobl, 1894 (Diptera, Scathophagidae) in the fauna of Russia // Russian Entomological Journal. Vol.18. No.4(2009). P.309317.

Ozerov A.L. 2010c. A review of Palaearctic species of the genera Delina Robineau-Desvoidy, 1830 and Neochirosia Malloch, 1917 (Insecta: Diptera: Scathophagidae) // Russian Entomological Journal. Vol.18. No.3. P.235-241.

Ozerov A.L. 2010d. Five new species of Scathophagidae (Diptera) from Russia // Russian Entomological Journal. Vol.19. No.2. P.157-166.

Ozerov A.L. 2010e. Review of Palaearctic species of Nanna Strobl, 1894 (Diptera, Scathophagidae) with shining stripes or spots on scutum // Far Eastern Entomologist. No.214. P.1-8.

Ozerov A.L. 2012. A review of World species of the genus Spaziphora Rondani, 1856 (Diptera, Scathophagidae) // Russian Entomological Journal. Vol.20. No.4(2011). P.423-430.

Ozerov A.L. 2013. Description of five new species and notes on taxonomy of Scathophagidae (Diptera) // Russian Entomological Journal. Vol.22. No.1. P.81-89.

Ozerov A.L. 2014. The Primary Types of Scathophagidae (Diptera) in the Museum für Naturkunde Berlin, and Senckenberg Deutsches Entomologisches Institut, Germany // Zoosystematics and Evolution. Vol.90. No.1. P.33-43.

Ozerov A.L., Krivosheina M.G. 2011. To the knowledge of dung flies (Diptera, Scathophagidae) of Vietnam, with the description of a new species // Far Eastern Entomologist. No.228. P.1-10.

Ozerov A.L., Krivosheina M.G. 2012a. A review of World species of the genus Pleurochaetella Vockeroth, 1965 (Diptera, Scathophagidae) // Russian Entomological Journal. Vol.21. No.4. P.435-440.

Ozerov A.L., Krivosheina M.G. 2012b. To knowledge of the genus Cordilura Fallén (Diptera, Scathophagidae), with description 
of a new species from the Russian Far East // Far Eastern Entomologist. No.249. P.1-4.

Ozerov A.L., Krivosheina M.G. 2013a. Types of Scathophagidae (Diptera) at the Zoological Institute of Russian Academy of Sciences, St Petersburg // Zoosystematica Rossica. Vol.22. No.1. P.141-149.

Ozerov A.L., Krivosheina M.G. 2013b. New and little known palaearctic species of Scathophagidae (Diptera) // Far Eastern Entomologist. No.270. P.1-6.

Ozerov A.L., Krivosheina M.G. 2014. A review of species of the genera Bostrichopyga Becker, 1894 and Paracosmetopus Hackman, 1956 (Diptera, Scathophagidae) // Russian Entomological Journal. Vol.23. No.1. P.85-90.

Sasakawa M. 1986. Two new species of the genus Cordilura Fallén (Diptera, Scatophagidae) from Japan // Proceedings of the Japanese Society of Systematic Zoology. No.33. P.40-44.

Šifner F. 1975. Scatophagidae (Diptera) de Mongolie // Annales Historico-Naturales Musei Nationalis Hungarici. Vol.67. P.219-227.

Šifner F. 1981. Les résultats de l'expédition entomologique Tchécoslovaque-Iranienne á l'Iran en 1973 // Acta Entomologica Musei Nationalis Pragae. Vol.40. P. 95-104.

Šifner F. 2003. The family Scathophagidae (Diptera) of the Czech and Slovak Republics (with notes on selected Palaearctic taxa) // Acta Musei Nationalis Pragae. Series B, Natural History. Vol.59. No 1-2. P.1-90.
Šifner F. 2008. A catalogue of the Scathophagidae (Diptera) of the Palaearctic region, with notes on their taxonomy and faunistics // Acta Entomologica Musei Nationalis Pragae. Vol.48. No.1. P.111-196.

Stackelberg A.A. 1952. [New species of Cordyluridae (Diptera) from North of USSR] // Trudy Zoologicheskogo Instituta AN SSSR. Vol.12. P.405-407 [in Russian].

Stuckenberg B.R. 1999. Antennal evolution in the Brachycera (Diptera), with a reassessment of terminology relating to the flagellum // Studia Dipterologica. Vol.6. S.33-48.

Suh S.J., Kwon Y.J., Jo T.H. 2007. Taxonomy of the genus Scathophaga Meigen (Diptera: Scathophagidae) in Korea // Entomological Research. Vol.37. P.290-293.

Sun X. 1996. Scathophagidae // Xue Wanqi (Hsue Wan-chi), Chao Chienming (eds.). Flies of China. Vol.1. Liaoning Science and Technology Press. Shenyang. P.622-633.

Vockeroth J.R. 1965. Subfamily Scatophaginae // Stone A. et al. (eds.). A catalog of the Diptera of America north of Mexico. United States Department of Agriculture. Agriculture Handbook. No.276. P.826-842.

Vockeroth J. R. 1977. Family Scathophagidae // Delfinado M.D., Hardy D.E. (eds.). A Catalog of the Diptera of the Oriental Region. Vol. 3. Suborder Cyclorrhapha (excluding Division Aschiza). The University Press of Hawaii. Honolulu. P.436438. 